\title{
Drivers of changes in stratospheric and tropospheric ozone between year 2000 and 2100
}

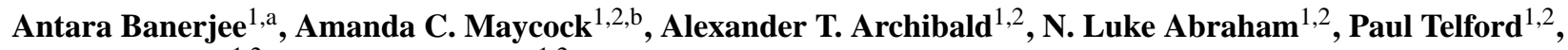 \\ Peter Braesicke $^{1,2, \mathrm{c}}$, and John A. Pyle ${ }^{1,2}$ \\ ${ }^{1}$ Department of Chemistry, University of Cambridge, Cambridge, UK \\ ${ }^{2}$ NCAS-Climate, Department of Chemistry, University of Cambridge, Cambridge, UK \\ ${ }^{a}$ now at: Department of Applied Physics and Applied Mathematics, Columbia University, New York, NY, USA \\ bnow at: School of Earth and Environment, University of Leeds, Leeds, UK \\ ${ }^{c}$ now at: Karlsruhe Institute of Technology, Institute for Meteorology and Climate Research, Karlsruhe, Germany \\ Correspondence to: Antara Banerjee (ab4283@columbia.edu)
}

Received: 22 September 2015 - Published in Atmos. Chem. Phys. Discuss.: 5 November 2015

Revised: 9 February 2016 - Accepted: 13 February 2016 - Published: 4 March 2016

\begin{abstract}
A stratosphere-resolving configuration of the Met Office's Unified Model (UM) with the United Kingdom Chemistry and Aerosols (UKCA) scheme is used to investigate the atmospheric response to changes in (a) greenhouse gases and climate, (b) ozone-depleting substances (ODSs) and (c) non-methane ozone precursor emissions. A suite of time-slice experiments show the separate, as well as pairwise, impacts of these perturbations between the years 2000 and 2100. Sensitivity to uncertainties in future greenhouse gases and aerosols is explored through the use of the Representative Concentration Pathway (RCP) 4.5 and 8.5 scenarios.

The results highlight an important role for the stratosphere in determining the annual mean tropospheric ozone response, primarily through stratosphere-troposphere exchange (STE) of ozone. Under both climate change and reductions in ODSs, increases in STE offset decreases in net chemical production and act to increase the tropospheric ozone burden. This opposes the effects of projected decreases in ozone precursors through measures to improve air quality, which act to reduce the ozone burden.

The global tropospheric lifetime of ozone $\left(\tau_{\mathrm{O}_{3}}\right)$ does not change significantly under climate change at RCP4.5, but it decreases at RCP8.5. This opposes the increases in $\tau_{\mathrm{O}_{3}}$ simulated under reductions in ODSs and ozone precursor emissions.

The additivity of the changes in ozone is examined by comparing the sum of the responses in the single-forcing ex-
\end{abstract}

periments to those from equivalent combined-forcing experiments. Whilst the ozone responses to most forcing combinations are found to be approximately additive, non-additive changes are found in both the stratosphere and troposphere when a large climate forcing (RCP8.5) is combined with the effects of ODSs.

\section{Introduction}

Ozone is of special interest in atmospheric science due to its multiple roles as a radiatively active gas, an oxidising agent and a surface pollutant. Thus, future projections of its evolution are of particular importance for climate and air quality issues. During the 21st century, changes in climate, ozonedepleting substances (ODSs) and emissions of ozone precursor species are expected to be major factors governing ozone amounts and its distribution in the stratosphere and free troposphere and at the surface (e.g. Johnson et al., 1999; Jonsson et al., 2004; Hauglustaine et al., 2005; Zeng et al., 2008; Fiore et al., 2012; Revell et al., 2015). With the projected decline in ODSs following the Montreal Protocol, the relative contribution of very short-lived substances (VSLSs) to the halogen loading of the stratosphere is expected to increase. However, future changes in atmospheric transport, oxidant concentrations and the magnitude of VSLS emissions lead to considerable uncertainties in their impact on ozone (Dessens et al., 2009; Hossaini et al., 2012; Yang et 
al., 2014). The magnitudes of natural emission sources of tropospheric ozone precursors are also likely to be affected by future changes in climate and land use (Squire et al., 2014) through changes in, for example, wildfire activity (Yue et al., 2013), lightning activity (Grewe, 2009; Banerjee et al., 2014) and the amount of isoprene emitted from vegetation (Sanderson, 2003; Pacifico et al., 2009).

The latest Intergovernmental Panel on Climate Change (IPCC) report adopted representative concentration pathway (RCP) scenarios for future emissions of greenhouse gases and aerosols, which are labelled according to the total radiative forcing at the year 2100 relative to the preindustrial (RCP2.6, 4.5, 6.0 and 8.5). Future ODS emissions are equivalent for RCP4.5, 6.0 and 8.5 (Meinshausen et al., 2011). All RCPs share the assumption of stringent future air quality legislation, and include strong reductions in non-methane anthropogenic emissions. Projections of methane concentration vary greatly between the RCPs. RCP2.6, 4.5 and 6.0 assume different trajectories for methane, but all project a decrease by 2100 as compared to 2000 (van Vuuren et al., 2011). In contrast, RCP8.5 projects more than a doubling in methane over this period.

In the troposphere, the numerical budget of ozone is widely used as a metric to gain insight into processes controlling ozone amounts. In practice, many studies calculate the budget of odd oxygen $\left(\mathrm{O}_{x}\right)$ to account for species that rapidly interconvert with ozone. In this study, $\mathrm{O}_{x}$ is defined as the sum of ozone, $\mathrm{O}\left({ }^{3} \mathrm{P}\right), \mathrm{O}\left({ }^{1} \mathrm{D}\right), \mathrm{NO}_{2}, 2 \mathrm{NO}_{3}$, $3 \mathrm{~N}_{2} \mathrm{O}_{5}, \mathrm{HNO}_{3}, \mathrm{HNO}_{4}$, peroxyacetyl nitrate (PAN), peroxypropionyl nitrate (PPAN) and peroxymethacrylic nitric anhydride (MPAN). Although the exact definition varies between studies, in any case, ozone represents the majority of $\mathrm{O}_{x}$. The budget consists of four terms: chemical production $\left(P\left(\mathrm{O}_{x}\right)\right)$, chemical loss $\left(L\left(\mathrm{O}_{x}\right)\right)$, deposition to the surface $\left(D\left(\mathrm{O}_{x}\right)\right)$ and stratosphere-troposphere exchange (STE). The two chemical terms may be combined to give the net chemical production $\left(\mathrm{NCP}=P\left(\mathrm{O}_{x}\right)\right.$ minus $\left.L\left(\mathrm{O}_{x}\right)\right)$. STE is commonly inferred as the net transport of ozone from the stratosphere to the troposphere required to close the tropospheric budget; this is the definition employed throughout the remainder of this study, unless otherwise stated. The processes that determine tropospheric ozone are strongly buffered. As a result, the inter-model spread in estimates of the contemporary ozone burden (e.g. for the year 2000) is small compared to the spread in other terms of the budget, as evident from several multi-model comparisons (IPCC, 2001; Stevenson et al., 2006; Wild, 2007; Young et al., 2013).

There exists a large body of literature that assesses the impact of future climate change on tropospheric ozone, including the multi-model studies mentioned above. Several features are robust across models: increased tropospheric ozone destruction through increased water vapour abundances (e.g. Johnson et al., 1999), which, for most models, leads to a decrease in NCP, and an increase in STE due to a strengthened
Brewer-Dobson circulation (BDC) (e.g. Collins et al., 2003; Sudo et al., 2003; Zeng and Pyle, 2003).

On the other hand, isolating the impacts of declining ODS concentrations, and the associated recovery of stratospheric ozone, on tropospheric composition has received attention in only a few studies (Kawase et al., 2011; Morgenstern et al., 2013; Zhang et al., 2014). Effects could occur through two main mechanisms: (i) increases in STE and (ii) increases in overhead ozone column with concomitant reductions in tropospheric photolysis rates. In such ODS-only scenarios, the aforementioned studies have shown the increase in STE to be the dominant influence on the tropospheric ozone burden, while changes in photolysis rates drive a reduction in tropospheric concentrations of the hydroxyl radical $(\mathrm{OH})$ and increase the methane lifetime.

This study employs the Met Office's Unified Model containing the United Kingdom Chemistry and Aerosols submodel (UM-UKCA) in a process-based approach to separate the impacts of future changes in climate, ODSs and emissions of non-methane ozone precursors on ozone. The analysis focuses on changes between 2000 and 2100 under the RCP4.5 and 8.5 climate forcing scenarios. Note that future methane emissions are highly uncertain and changes in its abundance, particularly at RCP8.5, will likely have large tropospheric and stratospheric impacts (Randeniya et al., 2002; Fleming et al., 2011; Revell et al., 2012, 2015; Young et al., 2013) that are not the focus of this study. Instead, we wish to isolate other drivers of ozone changes, in particular, the role of a change in mean climate state at RCP8.5, without the assumption of a large increase in methane abundance. Hence, the methane boundary condition is kept fixed in all sensitivity tests, although its radiative forcing effect is included in future changes to climate.

Mechanisms for stratosphere-troposphere coupling are highlighted through changes in stratospheric circulation and in chemistry. We do not discuss the detailed mechanisms that underlie changes in the global circulation (e.g. McLandress and Shepherd, 2009; Butchart et al., 2010; Hardiman et al., 2013). Particular focus is rather placed on assessing impacts on the global burden of tropospheric ozone. To this end, the global, tropospheric $\mathrm{O}_{x}$ budget is analysed in detail. To the best of our knowledge, few other studies have diagnosed this budget for the RCP scenarios (Kawase et al., 2011), which, as discussed by Young et al. (2013), was a shortcoming of the recent Atmospheric Chemistry and Climate Model Intercomparison Project (ACCMIP).

In addition, of the five ACCMIP models that did diagnose the budget under future scenarios, only two had online and comprehensive calculations of stratospheric chemistry. The remaining models either calculated simplified stratospheric chemistry or applied a stratospheric ozone climatology. Differences in the representation of stratospheric chemistry likely contributed to the large reported inter-model range of STE in ACCMIP (Young et al., 2013). A focus of 
this study is thus on the role of the stratosphere in determining changes in tropospheric ozone.

A description of the UM-UKCA model and the experimental framework is given in Sect. 2. Results from the experiments are presented in two sections. Section 3 focuses on changes in temperature and stratospheric ozone. Section 4 then discusses tropospheric ozone and how, in particular, it is influenced by stratospheric effects. Concluding remarks are given in Sect. 5 .

\section{Methodology}

\subsection{Model description and experimental setup}

This study uses an atmosphere-only, stratosphere-resolving configuration of UM-UKCA at a resolution of N48L60 $\left(3.75^{\circ} \times 2.5^{\circ}\right.$, with 60 hybrid-height levels extending up to $84 \mathrm{~km})$. A detailed description of the model can be found in Banerjee et al. (2014). Briefly, the model combines the previously validated UKCA stratospheric (Morgenstern et al., 2009) and tropospheric (O'Connor et al., 2014) chemical schemes. These include stratospheric gas-phase ozone chemistry; heterogeneous reactions on polar stratospheric clouds (PSCs); and oxidation of methane, carbon monoxide (CO) and non-methane volatile organic compounds (NMVOCs). Natural forcings (volcanic eruptions, solar cycle variations) are not included in the experiments, but the model does internally generate the quasi-biennial oscillation (QBO). Emissions of $\mathrm{NO}_{x}$ from lightning $\left(L \mathrm{NO}_{x}\right)$ are parameterised as a function of cloud-top height (Price and Rind, 1992, 1994) and thus can vary with changes in convection (Banerjee et al., 2014). Ozone and water vapour are interactive between the chemistry and radiation schemes.

We present results from a series of time-slice experiments, forced with fixed seasonally varying boundary conditions. These include time-averaged sea surface temperatures (SSTs) and sea ice, a uniform fixed $\mathrm{CO}_{2}$ concentration, uniform surface mixing ratios for other greenhouse gases (GHGs) and ODSs, and emissions of $\mathrm{NO}_{x}, \mathrm{CO}$ and NMVOCs. Each simulation is integrated for 20 years, with the last 10 years used for analysis.

A control simulation (Base) is forced by full year 2000 conditions; the remaining experiments perturb one or more of the boundary conditions to year 2100 levels. The experiments are detailed in Table 1, which has been updated from Banerjee et al. (2014). The three types of perturbation detailed in that paper, and briefly described now, are as follows:

i. Climate change $(\triangle \mathrm{CC})$ - the climate is changed by varying SSTs, sea ice and GHG concentrations $\left(\mathrm{CO}_{2}\right.$, $\mathrm{CH}_{4}, \mathrm{~N}_{2} \mathrm{O}, \mathrm{CFCs}$ and $\mathrm{HCFCs}$ ) in the radiation scheme only. Perturbations to year 2100 levels follow two RCP scenarios - RCP4.5 and RCP8.5 (van Vuuren et al., 2011) - with climatological SSTs and sea ice obtained from simulations of the HadGEM2-CC coupled atmosphere-ocean model for these scenarios (HadGEM2 Development Team, 2011).

ii. Ozone-depleting substances $(\triangle \mathrm{ODS})-\mathrm{a}$ reduction in halogen-containing species to year 2100 levels. There exist some, but not large, differences in ODS concentrations between RCP scenarios, and thus RCP4.5 is arbitrarily adopted. Note that the abundance of ODSs at 2100 is still larger than that at 1960 . The change in ODSs is applied to the chemistry scheme only and is uncoupled from the radiation scheme.

iii. Ozone precursor emissions ( $\triangle \mathrm{O} 3$ pre $)$ - a reduction in $\mathrm{NO}_{x}, \mathrm{CO}$ and NMVOC emissions from anthropogenic and biomass burning sources is considered. The RCP4.5 scenario is also followed here, although this is somewhat arbitrary since all RCP scenarios project aggressive mitigations of these emissions, and there are not large differences between them (Lamarque et al., 2013). Methane and natural emissions (including isoprene emissions) remain unchanged.

We emphasise that methane remains at year 2000 levels within the chemistry scheme in all experiments, although, as mentioned, its radiative impact is included in the effects of future climate change.

\subsection{Stratospheric ozone tracer}

To isolate the influence of the stratosphere on the troposphere through STE, we implement a "stratospheric ozone" tracer, $\mathrm{O}_{3} \mathrm{~S}$, into the model in a manner similar to Collins et al. (2003). In the stratosphere, defined as altitudes above the thermal tropopause (WMO, 1957), $\mathrm{O}_{3} \mathrm{~S}$ is constrained to equal ozone at every model time step. In the troposphere, $\mathrm{O}_{3} \mathrm{~S}$ evolves freely. Following Roelofs and Lelieveld (1997), $\mathrm{O}_{3} \mathrm{~S}$ has no tropospheric chemical production (unlike tropospheric ozone, which is formed from $\mathrm{NO}_{2}$ photolysis); however, we do consider its loss through $\mathrm{O}\left({ }^{1} \mathrm{D}\right)+\mathrm{H}_{2} \mathrm{O}$, $\mathrm{HO}_{2}+\mathrm{O}_{3}, \mathrm{OH}+\mathrm{O}_{3}$ and dry deposition. Loss of $\mathrm{O}_{3} \mathrm{~S}$ through reactions which conserve $\mathrm{O}_{x}$ is not considered. In this way, ozone that originates in the stratosphere can be traced through the troposphere.

The $\mathrm{O}_{3} \mathrm{~S}$ tracer was implemented in the following experiments: Base, $\triangle \mathrm{CC} 8.5, \triangle \mathrm{ODS}$ and $\Delta(\mathrm{CC} 8.5+\mathrm{ODS})$, using the model-simulated, time-varying thermal tropopause height and ozone field of each run. The impact of the choice of tropopause definition on $\mathrm{O}_{3} \mathrm{~S}$ has not been investigated; Lin et al. (2012) find in their CCM that seasonally averaged surface $\mathrm{O}_{3} \mathrm{~S}$ abundances are 5-8 ppbv higher when defined by the thermal tropopause compared to the "e90 tropopause", which essentially differentiates tropospheric from stratospheric air based on mixing timescales (Prather et al., 2011). However, although there are quantitative differences in absolute $\mathrm{O}_{3} \mathrm{~S}$ abundances between different tropopause definitions, the qualitative conclusions drawn in Sect. 4.5.2 regarding changes in $\mathrm{O}_{3} \mathrm{~S}$ are unlikely to depend upon this choice. 
Table 1. List of model simulations.

\begin{tabular}{|c|c|c|c|}
\hline Experiment & $\begin{array}{r}\text { Climate } \\
\left(\mathrm{SSTs}, \text { sea ice, } \mathrm{GHGs}^{\mathrm{a}}\right)\end{array}$ & $\begin{array}{r}\text { ODSs } \\
\text { (total chlorine, bromine }{ }^{b} \text { ) }\end{array}$ & $\begin{array}{r}\text { Ozone precursor } \\
\text { emissions }\end{array}$ \\
\hline Base & 2000 & 2000 & 2000 \\
\hline$\Delta \mathrm{CC} 4.5$ & 2100 (RCP4.5) & 2000 & 2000 \\
\hline$\Delta \mathrm{CC} 8.5$ & 2100 (RCP8.5) & 2000 & 2000 \\
\hline$\triangle \mathrm{ODS}$ & 2000 & 2100 (RCP4.5) & 2000 \\
\hline$\Delta \mathrm{O} 3$ pre & 2000 & 2000 & 2100 (RCP4.5) \\
\hline$\Delta(\mathrm{CC} 4.5+\mathrm{ODS})$ & 2100 (RCP4.5) & 2100 (RCP4.5) & 2000 \\
\hline$\Delta(\mathrm{CC} 4.5+\mathrm{O} 3$ pre $)$ & 2100 (RCP4.5) & 2000 & 2100 (RCP4.5) \\
\hline$\Delta(\mathrm{CC} 8.5+\mathrm{ODS})$ & 2100 (RCP8.5) & 2100 (RCP4.5) & 2000 \\
\hline$\Delta(\mathrm{CC} 8.5+\mathrm{O} 3$ pre $)$ & 2100 (RCP8.5) & 2000 & 2100 (RCP4.5) \\
\hline$\Delta(\mathrm{ODS}+\mathrm{O} 3$ pre $)$ & 2000 & 2100 (RCP4.5) & 2100 (RCP4.5) \\
\hline
\end{tabular}

\section{Stratospheric ozone}

Figure 1 shows changes in zonal and annual mean ozone and temperature compared to the Base run for experiments in which a single type of perturbation has been imposed in turn. Figure 2 shows changes in stratospheric and tropospheric column ozone over the tropics for the single- and combined-forcing experiments. The tropics are highlighted as a region of particular interest, since it is here that total column ozone is not expected to recover to pre-1980 values this century (Austin et al., 2010; WMO, 2011; Eyring et al., 2013). Although some discussion of tropospheric ozone is given, the following subsections focus mainly on stratospheric changes. Whilst many of these results have, at least qualitatively, been established in other studies, the aim is to highlight those changes in the large-scale stratospheric state which bear some relevance for tropospheric ozone, which is discussed in Sect. 4.

\subsection{Climate change under RCP4.5 and 8.5}

Experiments $\triangle \mathrm{CC} 4.5$ and $\triangle \mathrm{CC} 8.5$ show a pattern of temperature response (Fig. 1b and d) that is robust across climate models (IPCC, 2013). The troposphere warms across the globe, with a maximum change in excess of $3 / 9 \mathrm{~K}$ $(\Delta \mathrm{CC} 4.5 / \Delta \mathrm{CC} 8.5)$ in the tropical upper troposphere; the stratosphere cools, primarily due to increased longwave emission by $\mathrm{CO}_{2}$ (Fels et al., 1980). In the middle and upper stratosphere, where $\mathrm{O}_{x}$ (i.e. $\mathrm{O}+\mathrm{O}_{3}$ here) is in photochemical steady state, it is well established that cooling slows down the rate of catalytic $\mathrm{O}_{x}$ destroying cycles (Haigh and Pyle, 1982; Jonsson et al., 2004). This effect leads to ozone increases in this region (Fig. 1a and c), which partly mitigate the $\mathrm{CO}_{2}$ induced cooling through increased absorption of shortwave radiation. The magnitude of this effect has been quantified using simulations (not otherwise discussed) performed un- der $\Delta \mathrm{CC} 4.5 / \Delta \mathrm{CC} 8.5$ forcings, but in which a fixed, timevarying $3-\mathrm{D}$ ozone climatology from the Base run is employed in the calculation of radiative heating rates. These simulations show the radiative offset of ozone changes to reach $2 / 4 \mathrm{~K}(\Delta \mathrm{CC} 4.5 / \Delta \mathrm{CC} 8.5)$ at $40 \mathrm{~km}$.

In the tropical lower stratosphere, where photochemical lifetimes are long and ozone is predominantly under dynamical control, a decrease in ozone arises from enhanced upwelling of ozone-poor air from the troposphere, which is associated with a strengthened BDC (e.g. SPARC CCMVal, 2010; WMO, 2011; IPCC, 2013). This localised decrease in ozone is enhanced by the greater overlying ozone column, which reduces chemical production due to the "reversed selfhealing" effect (Haigh and Pyle, 1982; Meul et al., 2014), but this is partly mitigated by increases in lightning-derived ozone/ $\mathrm{NO}_{x}$ due to deeper convection in a warmer climate (Banerjee et al., 2014).

For the tropical stratospheric ozone column, Fig. 2 illustrates a very small and statistically insignificant increase of $0.2 \mathrm{DU}(0.1 \%)$ in $\triangle \mathrm{CC} 4.5$ but a decrease of $4.7 \mathrm{DU}$ ( $2 \%$ ) in $\Delta \mathrm{CC} 8.5$. Thus, the opposite-signed ozone changes in the lower and upper tropical stratosphere do not scale similarly with climate forcing in their contribution to the partial column. Whilst there is a near cancellation between these effects in $\triangle \mathrm{CC} 4.5$, the stronger BDC dominates in $\Delta$ CC8.5. These results are qualitatively consistent with those from transient Coupled Model Intercomparison Project Phase 5 (CMIP5) simulations using chemistry-climate models (CCMs) (Eyring et al., 2013).

With regards to the changes in tropical tropospheric column ozone, $L \mathrm{NO}_{x}$ is largely responsible for the $3.6 / 5.1 \mathrm{DU}$ $(10 / 14 \%)(\Delta C C 4.5 / \Delta C C 8.5)$ increases shown in Fig. 2. Thus the small net change in total column ozone in $\triangle \mathrm{CC} 8.5$ reflects a strong cancellation between the changes in stratospheric and tropospheric partial columns. The global tropo- 

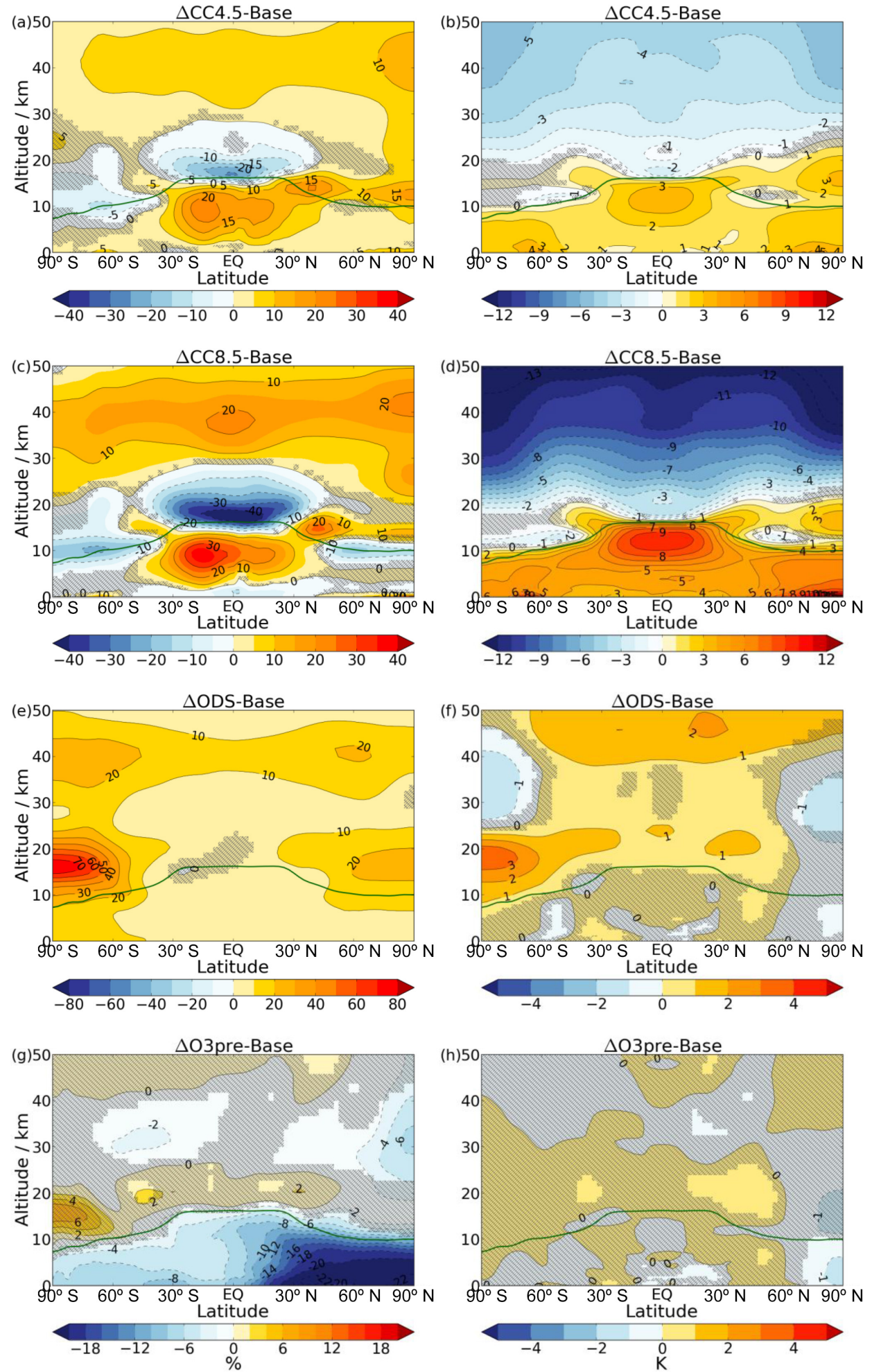

Figure 1. Changes in annual and zonal mean ozone (first column) and temperature (second column) for single-forcing experiments. Areas where the changes are not statistically significant at the $95 \%$ level according to a two-tailed Student's $t$ test are hatched out. The solid green line shows the thermal tropopause of the Base run. 


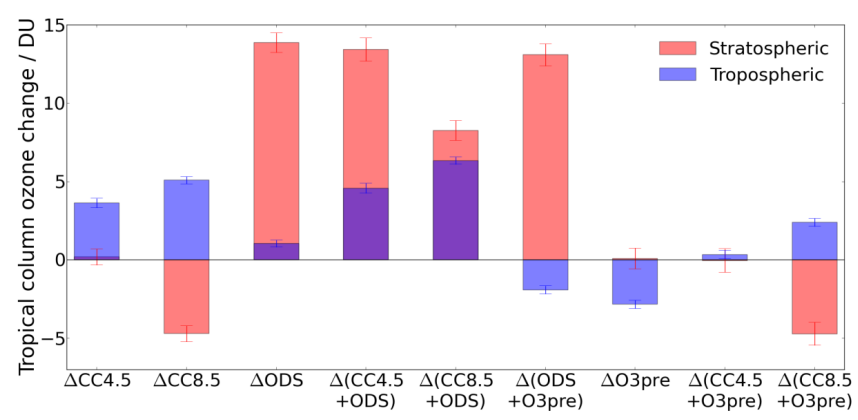

Figure 2. Changes in annual mean, area-weighted tropical $\left(30^{\circ} \mathrm{S}-\right.$ $30^{\circ} \mathrm{N}$ ) stratospheric (red) and tropospheric (blue) column ozone for the single- and combined-forcing experiments relative to Base. Partial columns are calculated assuming a thermal tropopause and a $50 \mathrm{~km}$ stratopause. Error bars indicate the 5-95\% confidence interval, calculated as \pm 1.96 times the standard error in the mean of the change.

spheric ozone response also contains an important contribution from increased stratosphere-to-troposphere transport, which will be discussed in Sect. 4 .

\subsection{Reductions in ODSs}

Reductions in the abundance of inorganic chlorine $\left(\mathrm{Cl}_{y}\right)$ and bromine $\left(\mathrm{Br}_{y}\right)$ following a reduction in ODS concentrations during the coming century lead to a ubiquitous increase in stratospheric ozone through homogeneous and heterogeneous chemical reactions. This is demonstrated in Fig. 1e for the $\triangle \mathrm{ODS}$ simulation, with Fig. 1f showing the corresponding temperature change. Figure 2 shows that, within the set of experiments, $\triangle$ ODS displays the largest increase (13.9 DU, $6 \%$ ) in tropical stratospheric column ozone.

Increased ozone in the upper stratosphere (Fig. 1e) is primarily attributable to reduced gas-phase $\mathrm{ClO}_{x}$-catalysed loss. This is partly offset by increases in the abundance of both $\mathrm{NO}_{x}$ and $\mathrm{HO}_{x}$, through reductions in the abundance of the $\mathrm{ClONO}_{2}$ reservoir (not shown) and decreases in the flux through the reactions $\mathrm{HCl}+\mathrm{OH}$ and $\mathrm{ClO}+\mathrm{HO}_{2}$ (Stenke and Grewe, 2005), respectively.

The largest local changes in ozone occur in the polar lower stratosphere in both hemispheres as a result of reductions in PSC-induced chlorine and bromine catalysed ozone loss. Increases in ozone between 18 and $20 \mathrm{~km}$ exceed $40 \%$ (April) over the Arctic and $400 \%$ (November) over the Antarctic, where ozone is strongly depleted in the Base run; associated increases in shortwave heating increase lower stratospheric temperatures, which is evident in the annual mean change over Antarctica (Fig. 1f). Note that the tropospheric temperature response cannot be assessed here since it is strongly limited by the use of fixed, year 2000 SSTs and sea ice. The response is likely to be small: McLandress et al. (2012) find only small tropospheric warming (Antarctic) and cool- ing (Arctic) due to ozone recovery between 2001 and 2050 in their model.

Section 4 will demonstrate that the changes in lower stratospheric ozone have a strong influence on tropospheric ozone, particularly in the extratropics. In contrast, Fig. 2 shows that, in the tropics, $\triangle \mathrm{ODS}$ is associated with only a small increase in tropospheric column ozone (1.0 DU, $3 \%$ ).

\subsection{Reductions in ozone precursor emissions}

The decreases in $\mathrm{NO}_{x}, \mathrm{CO}$ and NMVOC emissions in the $\Delta O 3$ pre simulation result in decreased ozone throughout the troposphere (Fig. 1g). Local changes are largest in the Northern Hemisphere (NH), where reductions in emissions are greatest (e.g. total $\mathrm{NO}_{x}$ emissions are reduced by $20.8 \mathrm{Tg}(\mathrm{N}) \mathrm{yr}^{-1}, 91 \%$ of which is in the $\left.\mathrm{NH}\right)$. It is notable that this is the only type of perturbation considered in this study that acts to decrease tropical tropospheric column ozone (Fig. 2).

The changes in ozone precursor emissions in the $\Delta \mathrm{O} 3$ pre experiment do not have a significant effect on stratospheric ozone abundances. The changes in temperature (Fig. 1h) are also insignificant, although since the experiments include fixed SSTs, the full radiative effect of ozone changes on tropospheric temperatures will not be captured.

Thus, in the $\Delta \mathrm{O} 3$ pre experiment, the troposphere exerts no significant influence on the stratosphere. Note that we have not explored the impact of changes in biogenic emissions, which are likely to be largest in the tropics (Squire et al., 2014), and could thus impact the stratosphere through convective lofting of ozone or its precursors into the upper troposphere-lower stratosphere (UTLS) (Hauglustaine et al., 2005).

\subsection{Stratospheric additivity}

Generally, changes in annual and zonal mean ozone and temperature for the combined-forcing runs $\Delta(\mathrm{CC} 4.5+\mathrm{ODS})$, $\Delta(\mathrm{CC} 8.5+\mathrm{ODS}), \Delta(\mathrm{CC} 4.5+\mathrm{O} 3 \mathrm{pre}), \Delta(\mathrm{CC} 8.5+\mathrm{O} 3 \mathrm{pre})$ and $\Delta(\mathrm{ODS}+\mathrm{O} 3$ pre $)$ can be closely reproduced from summing changes in the respective single-forcing runs.

The exception is the ozone response in $\Delta(\mathrm{CC} 8.5+\mathrm{ODS})$, in which two regions of small, but statistically significant, non-additivities are found (shading, Fig. 3b). The first is located in the upper stratosphere, where the response to climate change and reduced ODSs reinforce one another (Chipperfield and Feng, 2003). Here, the simulated increase in ozone is around $0.2 \mathrm{ppmv}$ greater than that calculated from a linear addition of the $\triangle \mathrm{CC} 8.5$ and $\triangle \mathrm{ODS}$ perturbations. The effect is caused by a change in the temperature dependence of catalytic ozone loss (positive if evaluated by $\mathrm{d} \ln \left[\mathrm{O}_{3}\right] / \mathrm{d} T^{-1}$ as in Haigh and Pyle, 1982) with a reduction in halogen loading. This is essentially the same effect found by Haigh and Pyle (1982) in their experiment combining a doubling in $\mathrm{CO}_{2}$ with increases in ODS concentrations. 

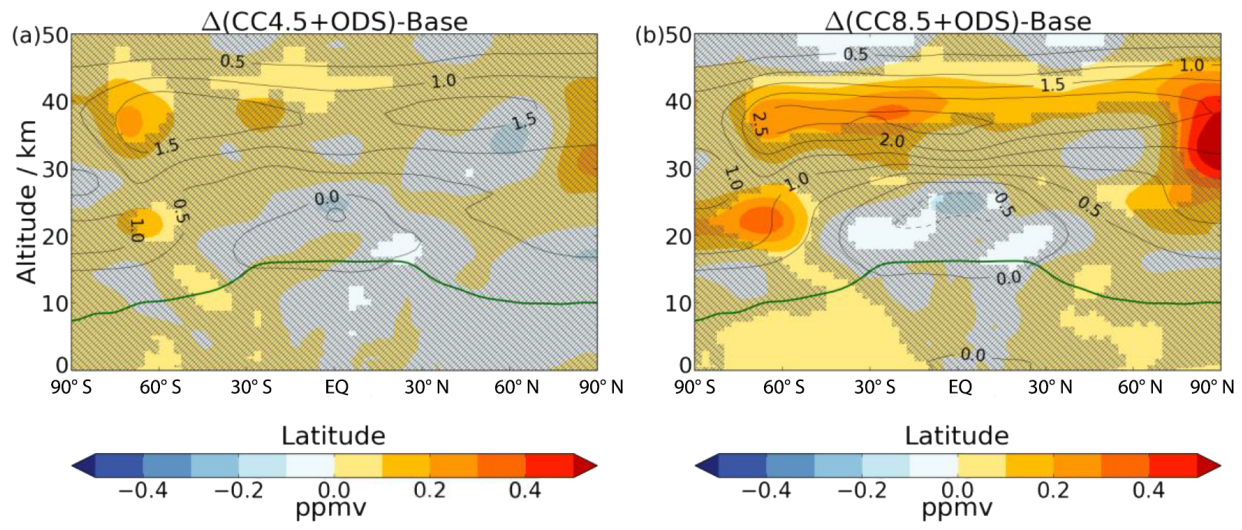

Figure 3. Changes in annual and zonal mean ozone (ppmv, contours) from Base to two combined-forcing runs: (a) $\Delta$ (CC4.5+ODS) and (b) $\Delta$ (CC8.5+ODS). The shading indicates the amount by which the response deviates from additivity (i.e. the difference between the combined-forcing experiment and the sum of the individual-forcing cases). Areas where the non-additive component of the response is not significant at the $95 \%$ level according to a Student's $t$ test are hatched out. The solid green line indicates the thermal tropopause of the Base run.

The second region where the $\Delta(\mathrm{CC} 8.5+\mathrm{ODS})$ response is non-additive is the lower stratosphere at around $60^{\circ} \mathrm{S}$; this can be ascribed to a non-additivity in the amount of chlorine activated through heterogeneous reactions of reservoir species $\left(\mathrm{ClONO}_{2}\right.$ and $\left.\mathrm{HCl}\right)$ on PSCs and sulfate aerosols. This can be rationalised by considering the rate of these reactions, which is proportional to the product of PSC/aerosol surface area density (SAD) and $[\mathrm{Cl}$ reservoir]. Thus, when [Cl reservoir] is low (e.g. due to the lower $\mathrm{Cl}_{y}$ loadings in $\triangle \mathrm{ODS}$ ), increases in the rate of reaction due to increases in SAD (e.g. due to cooling under climate change) are smaller. Therefore, in $\Delta(\mathrm{CC} 8.5+\mathrm{ODS})$, reductions in active chlorine $\left(\mathrm{ClO}_{x}\right)$ are greater than expected from their separate effects, and hence the ozone concentration is higher. These effects occur primarily at the edge of the vortex, where cooling under climate change leads to greater PSC formation and hence $\mathrm{ClO}_{x}$ concentrations. In contrast, in the cold core of the vortex, cooling under climate change does not greatly affect PSC areas, since temperatures are already below the PSC formation threshold in the Base experiment.

For both the upper and lower stratosphere, the magnitude of the deviation from additivity scales with the amount of stratospheric cooling. Thus, the effects are present to a much lesser extent when combining $\triangle \mathrm{ODS}$ with $\triangle \mathrm{CC} 4.5$ (Fig. 3a), which causes around a third of the stratospheric cooling found under $\triangle \mathrm{CC} 8.5$ (Fig. $1 \mathrm{~b}$ and d).

Note that scenarios in which $\mathrm{CH}_{4}$ or $\mathrm{N}_{2} \mathrm{O}$ are changed in the chemistry scheme have not been explored. If such perturbations were combined with $\triangle \mathrm{ODS}$, non-additive responses would be expected since both $\mathrm{CH}_{4}$ and $\mathrm{N}_{2} \mathrm{O}$ control chlorine partitioning (through $\mathrm{CH}_{4}+\mathrm{Cl} \rightarrow \mathrm{HCl}+\mathrm{CH}_{3}$ and $\mathrm{NO}_{2}+\mathrm{ClO}+\mathrm{M} \rightarrow \mathrm{ClONO}_{2}+\mathrm{M}$, respectively) (e.g. Fleming et al., 2011; Portmann et al., 2012; Meul et al., 2015).

Overall, the stratospheric changes are largely as expected from theory and previous model studies (e.g. Haigh and Pyle,
1982; Jonsson et al., 2004; Austin et al., 2010; Eyring et al., 2013; Meul et al., 2014). Insight into the impact of methane changes, which are not explored here, can also be garnered from previous literature (Randeniya et al., 2002; Stenke and Grewe, 2005; Portmann and Solomon, 2007; Fleming et al., 2011; Revell et al., 2012). These studies conclude that the stratospheric ozone response to increased methane results from a combination of increased $\mathrm{HO}_{x}$-catalysed destruction (upper stratosphere), enhanced production through smoglike chemistry (lower stratosphere), and reduced losses due to water-vapour-induced cooling and reductions in $\left[\mathrm{ClO}_{x}\right]$. Overall, Revell et al. (2012) find positive linear relationships between end of 21 st century surface methane abundances and stratospheric column ozone across the four RCPs in the NIWA-SOCOL CCM.

We have demonstrated that the stratosphere is not strongly influenced by chemical changes in the free troposphere in these experiments. However, changes in stratospheric composition and dynamics might have important impacts on the troposphere. To determine the extent of these impacts, the next section provides a detailed analysis of the troposphere.

\section{Tropospheric ozone}

This section focuses on the global burden of ozone and its lifetime in the troposphere. The role of changes in both chemical production/loss and STE of ozone are discussed. One key aim is to ascertain the influence of the stratosphere on the troposphere, which, as will be shown, mainly occurs through STE. Consequences of changes in STE are highlighted not only for the global ozone burden but also for its latitude-height distribution. Where reported, errors represent the 5-95\% confidence interval, as calculated from the standard deviation in 10 yearly-mean values for UM-UKCA ex- 
Table 2. Tropospheric $\mathrm{O}_{x}$ budget for the experiments detailed in Table 1. The definition of $\mathrm{O}_{x}$ employed here is given in the Introduction. Also reported is the tropospheric lifetime of ozone $\left(\tau_{\mathrm{O}_{3}}\right)$ and whole atmosphere lifetime of methane $\left(\tau_{\mathrm{CH}_{4}}\right)$. The latter includes loss by tropospheric $\mathrm{OH}$ (diagnosed by the model), a soil sink (lifetime 160 years) and a stratospheric sink (lifetime 120 years). The final column shows values of the ozone burden after adjusting to account for methane feedbacks ( $\left.B_{\text {adj }}\right)$ (see Sect. 4.3 for details). Two sets of multi-model means for the year 2000 are included for comparison with the Base run: ACCENT values (first row) are taken from or calculated from data in Stevenson et al. (2006), and ACCMIP (second row) from Young et al. (2013) for all terms except $\tau_{\mathrm{CH}_{4}}$, which has been calculated from the tropospheric methane lifetimes reported in Naik et al. (2013). Note that, in this study, the $D\left(\mathrm{O}_{x}\right)$ term totals dry deposition of ozone (listed in brackets) plus deposition of those reactive nitrogen compounds that are classed as $\mathrm{O}_{x}$, whereas the ACCENT and ACCMIP studies only report the former. The same applies in the calculation of $\tau_{\mathrm{O}_{3}}$.

\begin{tabular}{|c|c|c|c|c|c|c|c|c|c|c|c|}
\hline Experiment & $\begin{array}{r}P\left(\mathrm{O}_{x}\right) / \\
\operatorname{Tg}\left(\mathrm{O}_{3}\right) \mathrm{yr}^{-1}\end{array}$ & $\begin{array}{r}L\left(\mathrm{O}_{x}\right) / \\
\operatorname{Tg}\left(\mathrm{O}_{3}\right) \mathrm{yr}^{-1}\end{array}$ & $\begin{array}{r}\text { NCP / } \\
\operatorname{Tg}\left(\mathrm{O}_{3}\right) \mathrm{yr}^{-1}\end{array}$ & $\begin{array}{r}D \\
\operatorname{Tg}(\mathrm{O}\end{array}$ & $\begin{array}{l}\left(\mathrm{O}_{x}\right) / \\
\mathrm{yr}^{-1}\end{array}$ & $\begin{array}{r}\text { STE / } \\
\operatorname{Tg}\left(\mathrm{O}_{3}\right) \mathrm{yr}^{-1}\end{array}$ & $\begin{array}{r}B / \\
\operatorname{Tg}\left(\mathrm{O}_{3}\right)\end{array}$ & & $\begin{array}{l}\tau_{\mathrm{O}_{3}} / \\
\text { days }\end{array}$ & $\begin{array}{l}{ }^{\tau} \mathrm{CH}_{4} / \\
\text { years }\end{array}$ & $\begin{array}{r}B_{\text {adj }} / \\
\operatorname{Tg}\left(\mathrm{O}_{3}\right)\end{array}$ \\
\hline ACCENT, year 2000 & $5110 \pm 606$ & $4668 \pm 727$ & $442 \pm 309$ & (1003 & $\pm 200)$ & $552 \pm 168$ & $344 \pm 39$ & $(22$ & $\pm 2.0)$ & $8.67 \pm 1.32$ & - \\
\hline ACCMIP, year 2000 & $4877 \pm 853$ & $4260 \pm 645$ & $618 \pm 275$ & (1094 & $\pm 264)$ & $477 \pm 96$ & $337 \pm 23$ & $(23$ & $+ \pm 2.2)$ & $8.5 \pm 1.1$ & - \\
\hline Base & 4872 & 4217 & 655 & 1015 & (871) & 360 & 326 & 22.5 & $(23.1)$ & 8.10 & - \\
\hline$\Delta \mathrm{CC} 4.5$ & 5287 & 4668 & 619 & 1041 & (889) & 422 & 356 & 22.4 & (23.0) & 7.32 & 349 \\
\hline$\Delta \mathrm{CC} 8.5$ & 5851 & 5305 & 546 & 1007 & (846) & 461 & 369 & 21.0 & (21.6) & 6.34 & 353 \\
\hline$\Delta \mathrm{ODS}$ & 4768 & 4168 & 600 & 1056 & (912) & 456 & 344 & 23.7 & (24.4) & 8.38 & 347 \\
\hline$\Delta \mathrm{O} 3$ pre & 4065 & 3643 & 422 & 820 & (736) & 398 & 292 & 23.5 & $(24.0)$ & 8.34 & 294 \\
\hline$\Delta(\mathrm{CC} 4.5+\mathrm{ODS})$ & 5186 & 4634 & 552 & 1081 & (930) & 529 & 374 & 23.6 & $(24.2)$ & 7.54 & 369 \\
\hline$\Delta(\mathrm{CC} 8.5+\mathrm{ODS})$ & 5742 & 5307 & 436 & 1054 & (893) & 619 & 393 & 22.3 & (22.8) & 6.49 & 378 \\
\hline$\Delta(\mathrm{CC} 4.5+\mathrm{O} 3$ pre $)$ & 4470 & 4090 & 380 & 847 & (756) & 467 & 319 & 23.3 & (23.7) & 7.50 & 314 \\
\hline$\Delta(\mathrm{CC} 8.5+\mathrm{O} 3 \mathrm{pre})$ & 5050 & 4720 & 331 & 828 & (728) & 497 & 337 & 21.8 & $(22.2)$ & 6.47 & 322 \\
\hline$\Delta(\mathrm{ODS}+\mathrm{O} 3$ pre $)$ & 4000 & 3633 & 366 & 858 & (774) & 492 & 308 & 24.7 & $(25.2)$ & 8.54 & 312 \\
\hline
\end{tabular}

periments; for multi-model means (Stevenson et al., 2006; Naik et al., 2013; Young et al., 2013), errors give the intermodel range as $1 \sigma$.

\subsection{Year 2000 tropospheric $O_{x}$ budget}

The global and annual mean $\mathrm{O}_{x}$ budget of the troposphere for all experiments is shown in Table 2. Multi-model mean values from the ACCENT ensemble (Stevenson et al., 2006) are included for comparison to the Base run. Values for the more recent ACCMIP ensemble are also shown, with the caveat that only six of those models diagnosed the $\mathrm{O}_{x}$ budget, although all 15 models diagnosed the ozone burden and methane lifetime (Naik et al., 2013; Young et al., 2013). For most terms, the Base run compares favourably with the ACCENT and ACCMIP results. Chemical production $\left(P\left(\mathrm{O}_{x}\right)\right)$, chemical loss $\left(L\left(\mathrm{O}_{x}\right)\right)$ and deposition are well within $1 \sigma$ of the multi-model means; we compare the dry deposition of ozone here (see Table 2) but consider deposition of all $\mathrm{O}_{x}\left(D\left(\mathrm{O}_{x}\right)\right)$ hereafter. However, the inferred STE of $360 \pm 14 \mathrm{Tg}\left(\mathrm{O}_{3}\right) \mathrm{yr}^{-1}$ is lower than observational estimates, which range between 450 and $550 \mathrm{Tg}\left(\mathrm{O}_{3}\right) \mathrm{yr}^{-1}$ (e.g. Gettelman et al., 1997; Olsen et al., 2001, 2013), and the ACCENT and ACCMIP means of $552 \pm 168$ and $477 \pm 96 \mathrm{Tg}\left(\mathrm{O}_{3}\right) \mathrm{yr}^{-1}$, respectively. Nevertheless, a comparison to these model intercomparisons is likely to be inadequate in this case - only three out of the six ACCMIP models that reported STE contained full stratospheric chemistry (Lamarque et al., 2013; Young et al., 2013), while almost none of the ACCENT models contained this representation. In addition, some models altered the stratospheric up- per boundary condition to match observational constraints, whereas STE cannot be predetermined in such a way in the UM-UKCA scheme.

The Base ozone burden of $326 \pm 2 \mathrm{Tg}\left(\mathrm{O}_{3}\right)$ is close to the ACCENT and ACCMIP ensemble means ( $344 \pm 39$ and $337 \pm 23 \operatorname{Tg}\left(\mathrm{O}_{3}\right)$, respectively). Note that the UM-UKCA budgets are calculated using the monthly mean thermal tropopause in contrast to the two model intercomparisons, which used a chemical tropopause defined by the $150 \mathrm{ppbv}$ contour of ozone. However, the $\mathrm{O}_{x}$ budget terms in the Base run do not differ greatly between the two definitions. At most, relative differences reach $2 \%$ for both the burden $\left(7 \mathrm{Tg}\left(\mathrm{O}_{3}\right)\right.$ lower $)$ and STE $\left(8 \mathrm{Tg}\left(\mathrm{O}_{3}\right) \mathrm{yr}^{-1}\right.$ greater $)$ when comparing the chemical with the thermal tropopause. Furthermore, observations obtained between 2004 and 2010 from the Ozone Monitoring Instrument (OMI) and Microwave Limb Sounder (MLS) (Ziemke et al., 2011) indicate a climatological, total ozone burden of $295 \mathrm{Tg}\left(\mathrm{O}_{3}\right)$ between the latitudes $60^{\circ} \mathrm{S}$ and $60^{\circ} \mathrm{N}$, which compares well with the value of $298 \mathrm{Tg}\left(\mathrm{O}_{3}\right)$ in the Base run.

Effects of the year 2100 perturbations on the ozone burden are now discussed, and the underlying causes investigated.

\subsection{Ozone burden}

To illustrate the effects of the year 2100 perturbations on ozone, the tropospheric burden is shown against (i) NCP (Fig. 4a) and (ii) STE (Fig. 4b). The magnitude of the changes in NCP and STE are compared since their absolute values are similarly large. The steady state ozone burden is a product of the ozone lifetime $\left(\tau_{\mathrm{O}_{3}}\right)$ and its total loss 

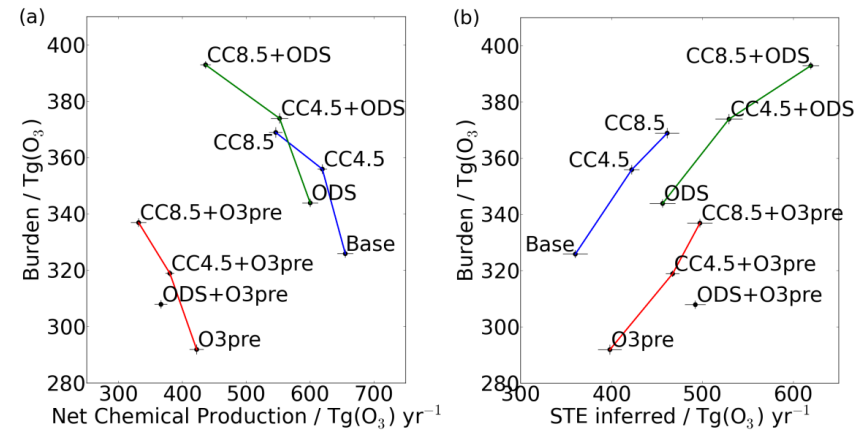

Figure 4. Tropospheric ozone burden against (a) NCP and (b) STE. Connecting lines are drawn between experiments which differ only in their climate states. Error bars denote the 5-95\% confidence interval, calculated as \pm 1.96 times the standard error in the mean.

or production rate (the "turnover flux"), so changes in these quantities are also considered. Note that, to ensure a physically consistent definition of the troposphere, the height of the tropopause is allowed to change in response to the climate perturbations in these experiments. Therefore, under climate change, a rising of the tropopause contributes to an increase in the ozone burden.

Reductions in emissions of ozone precursors lower the ozone burden; for the $\Delta \mathrm{O} 3$ pre experiment, a decrease of $34 \pm 2 \mathrm{Tg}\left(\mathrm{O}_{3}\right)(10.4 \%)$ is found despite an increase in $\tau_{\mathrm{O}_{3}}$ (Sect. 4.6). This is driven mainly by a decrease in chemical ozone production (Sect. 4.4), causing considerable reductions in both the turnover flux $\left(-769 \mathrm{Tg}\left(\mathrm{O}_{3}\right) \mathrm{yr}^{-1}\right)$ and $\mathrm{NCP}$ $\left(-233 \mathrm{Tg}\left(\mathrm{O}_{3}\right) \mathrm{yr}^{-1}\right.$, Fig. $\left.4 \mathrm{a}\right)$. This can be compared to a very small increase in STE of $38 \mathrm{Tg}\left(\mathrm{O}_{3}\right) \mathrm{yr}^{-1}$ (Fig. 4b) and a reduction in $D\left(\mathrm{O}_{x}\right)$ of $195 \mathrm{Tg}\left(\mathrm{O}_{3}\right) \mathrm{yr}^{-1}$ (Table 2).

In contrast, the ozone burden increases under climate change and lower ODS concentrations. For the single-forcing experiments, the increases are $30 \pm 2 \mathrm{Tg}\left(\mathrm{O}_{3}\right)$ $(9.2 \%)(\Delta \mathrm{CC} 4.5), 43 \pm 2 \mathrm{Tg}\left(\mathrm{O}_{3}\right)(13.2 \%)(\Delta \mathrm{CC} 8.5)$ and $18 \pm 2 \mathrm{Tg}\left(\mathrm{O}_{3}\right)(5.5 \%)(\Delta \mathrm{ODS})$. For $\Delta \mathrm{CC} 4.5 / \Delta \mathrm{CC} 8.5$, these are largely due to increases in the turnover flux of $477 / 1080 \operatorname{Tg}\left(\mathrm{O}_{3}\right) \mathrm{yr}^{-1}$, which occur alongside no change in $\tau_{\mathrm{O}_{3}}$ in $\Delta$ CC4.5 and a reduction in $\tau_{\mathrm{O}_{3}}$ in $\Delta \mathrm{CC} 8.5$ (Table 2, Sect. 4.6). For $\triangle \mathrm{ODS}$, there is a negligible change in the turnover flux $\left(-8 \mathrm{Tg}\left(\mathrm{O}_{3}\right) \mathrm{yr}^{-1}\right)$, but the ozone burden is increased as a result of higher $\tau_{\mathrm{O}_{3}}$ (Table 2, Sect. 4.6). In all of these experiments, large increases in STE of $62 / 101 / 96 \mathrm{Tg}\left(\mathrm{O}_{3}\right) \mathrm{yr}^{-1}(\Delta \mathrm{CC} 4.5 / \Delta \mathrm{CC} 8.5 / \Delta \mathrm{ODS})$ play a crucial role by increasing the ozone source and its lifetime (Fig. 4b, Sect. 4.6). These are comparable to, or larger than, the respective reductions in NCP of 36, 109 and $55 \mathrm{Tg}\left(\mathrm{O}_{3}\right) \mathrm{yr}^{-1}$ (Fig. 4a). $D\left(\mathrm{O}_{x}\right)$ shows smaller changes of $26,-8$ and $41 \mathrm{Tg}\left(\mathrm{O}_{3}\right) \mathrm{yr}^{-1}$, respectively (Table 2).

Banerjee et al. (2014) highlighted the importance of changes in $L \mathrm{NO}_{x}$ under climate change for increasing the ozone burden and hence opposing the effects of projected reductions in ozone precursors. The results presented here further demonstrate that increases in STE, though smaller in magnitude than changes in the chemical terms, are also an important contributor to the higher tropospheric ozone burden under climate change in these experiments (Table 2, Fig. 4). Furthermore, through increased STE, reduced ODSs also act to oppose the effects of $\Delta \mathrm{O} 3$ pre (Table 2, Fig. 4).

The response of the tropospheric budget terms to climate change is qualitatively consistent with results from most other model studies, which find reductions in NCP, increases in STE and increases in the turnover flux under various climate forcing scenarios (e.g. Stevenson et al., 2006; Zeng et al., 2008; Kawase et al., 2011; Morgenstern et al., 2013; Young et al., 2013). For the ozone burden, Kawase et al. (2011) also find increases under RCP4.5 and 8.5 in sensitivity tests that are similar to the $\triangle \mathrm{CC} 4.5$ and $\triangle \mathrm{CC} 8.5$ runs of this study. However, this response is likely to be modeldependent. For example, the ACCENT inter-model range in future changes in the ozone burden encompasses both increases and decreases for the same climate forcing scenario (Stevenson et al., 2006).

Note that we have not performed simulations that include all forcings. For the ACCMIP ensemble mean, the combined impact of all forcings on the ozone burden between 2000 and 2100 was found to be a decrease of $7 \%$ (RCP4.5) and an increase of $18 \%$ (RCP8.5), which is dominated by the effects of $\mathrm{NO}_{x} / \mathrm{CO} / \mathrm{NMVOC}$ emission reductions and an increase in methane, respectively (Young et al., 2013).

\subsection{Implications of methane adjustments for the ozone burden}

The tropospheric ozone burden is also affected by the method with which the methane boundary condition is applied in the model. All experiments include a uniform fixed lower boundary condition of $1.75 \mathrm{ppmv}$ for methane, which effectively fixes its abundance throughout the troposphere. Thus any changes in $\mathrm{OH}$ essentially do not affect methane concentrations, nor are any subsequent feedbacks captured. This includes the influence of methane on its own abundance (Isaksen and Hov, 1987) as well as on ozone.

The feedback factor, $f$ (e.g. Fuglestvedt, 1999), gives a measure of the influence of methane on its own lifetime, and has previously been estimated to be 1.52 for this model (Banerjee et al., 2014). Following the methodology in that study and references therein, the amount of methane and ozone that would be simulated at equilibrium if methane were allowed to evolve freely have been calculated using the whole atmosphere methane lifetime $\left(\tau_{\mathrm{CH}_{4}}\right)$ reported in Table 2; corresponding equilibrium ozone burdens are reported in the final column.

The estimated equilibrium ozone burdens are 7 and $16 \mathrm{Tg}\left(\mathrm{O}_{3}\right)$ smaller than simulated in the $\Delta \mathrm{CC} 4.5$ and $\triangle \mathrm{CC} 8.5$ experiments, respectively. In contrast, only a 3 and $2 \mathrm{Tg}\left(\mathrm{O}_{3}\right)$ increase in ozone burden compared to simulated values is estimated for the $\triangle \mathrm{ODS}$ and $\Delta \mathrm{O} 3$ pre ex- 
periments, respectively. Therefore, when considering the effects of methane adjustments, the extent to which climate change counters the impact of $\Delta \mathrm{O} 3$ pre on the ozone burden is somewhat reduced, while the extent to which $\triangle$ ODS counters $\Delta \mathrm{O} 3$ pre is slightly increased. Nonetheless, the qualitative conclusions remain unchanged.

Having discussed changes in the ozone burden, the following subsection further explores the tropospheric $\mathrm{O}_{x}$ budget and investigates the underlying causes of the changes in NCP and STE.

\subsection{Chemical production and loss}

To explore changes in NCP, Fig. 5 shows mean values for the Base experiment and the changes due to each type of perturbation in the primary $\mathrm{O}_{x}$ chemical production $\left(\mathrm{HO}_{2}+\mathrm{NO}, \mathrm{CH}_{3} \mathrm{O}_{2}+\mathrm{NO}\right.$ and $\mathrm{RO}_{2}+\mathrm{NO}$, where $\mathrm{RO}_{2}$ is a generic peroxy radical not including $\mathrm{HO}_{2}$ or $\mathrm{CH}_{3} \mathrm{O}_{2}$ ) and loss $\left(\mathrm{O}\left({ }^{1} \mathrm{D}\right)+\mathrm{H}_{2} \mathrm{O}, \mathrm{HO}_{2}+\mathrm{O}_{3}\right.$ and $\left.\mathrm{OH}+\mathrm{O}_{3}\right)$ routes. Together, these constitute 98 and $97 \%$ of total chemical production and loss of $\mathrm{O}_{x}$, respectively.

Figure 4a shows that reductions in NCP are largest when emissions of ozone precursors are reduced. Figure 5 b shows that this is driven by decreases in $P\left(\mathrm{O}_{x}\right)$, primarily through the $\mathrm{HO}_{2}+\mathrm{NO}$ reaction. Mitigation of $\mathrm{NO}_{x}$ emissions, and hence a reduction in $\mathrm{NO}$ concentrations, directly drive the majority of this response. Reductions in NMVOC and, in particular, $\mathrm{CO}$ emissions also contribute by slowing down $\mathrm{OH}$ to $\mathrm{HO}_{2}$ conversion, thus reducing $\mathrm{HO}_{2}$ concentrations. Additionally, the decreases in ozone also act to reduce $\mathrm{HO}_{x}$ abundances. We do not quantify the relative importance of these separate drivers.

The impact of climate change reduces NCP in the experiments, as can be seen from each set of connecting lines in Fig. 4a; this is in qualitative agreement with recent multimodel studies (Stevenson et al., 2006; Young et al., 2013). This is the result of greater $L\left(\mathrm{O}_{x}\right)$, which dominates over a smaller increase in $P\left(\mathrm{O}_{x}\right)$. Greater $L\left(\mathrm{O}_{x}\right)$ occurs primarily via increased $\mathrm{O}\left({ }^{1} \mathrm{D}\right)+\mathrm{H}_{2} \mathrm{O}$ (Fig. 5c) as atmospheric moisture content increases, and is a robust feature across models, although the magnitude will depend on the amplitude of tropospheric warming. Here, this is determined by the imposed SSTs and sea ice which are derived from a model that is part of the HadGEM2 family, known to lie on the upper end of the current modelled range of equilibrium climate sensitivities (Andrews et al., 2012). Greater $P\left(\mathrm{O}_{x}\right)$ occurs mainly due to increased $L \mathrm{NO}_{x}$ associated with changes in tropical convection (see Banerjee et al., 2014, for more details), although the importance of this effect relative to other drivers of $\mathrm{O}_{x}$ production is expected to be highly model-dependent. The fluxes through $\mathrm{HO}_{2}+\mathrm{NO}$ and $\mathrm{CH}_{3} \mathrm{O}_{2}+\mathrm{NO}$ (Fig. 5b) thus increase with climate change. Both $P\left(\mathrm{O}_{x}\right)$ and $L\left(\mathrm{O}_{x}\right)$ are amplified for the larger RCP8.5 climate forcing.

Figure $4 \mathrm{a}$ also shows that there are consistent reductions in NCP under lower ODS concentrations. For the $\triangle$ ODS
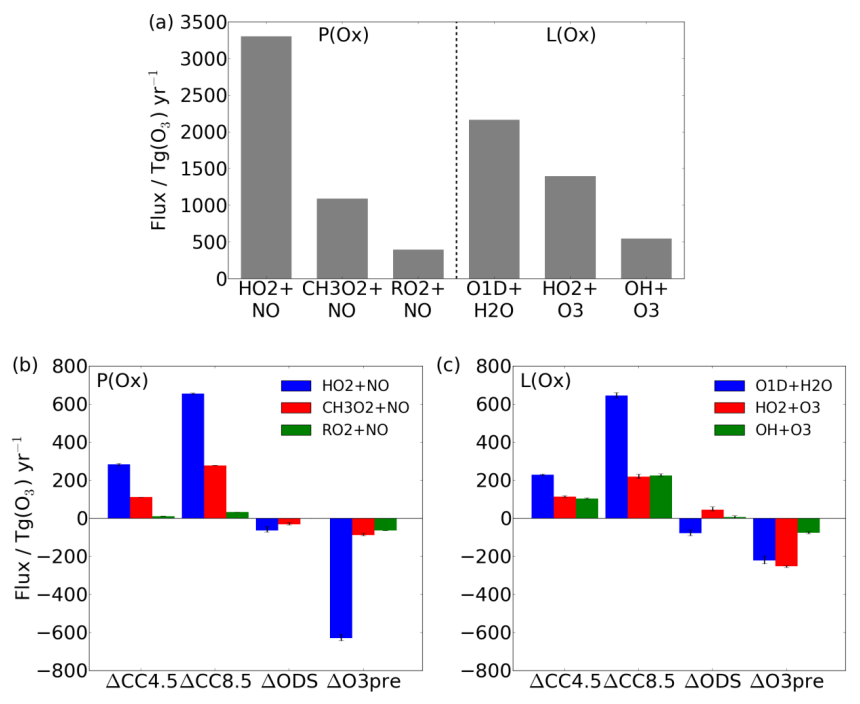

Figure 5. (a) Global tropospheric and annual mean fluxes in the Base run through the main channels for chemical production and loss of $\mathrm{O}_{x}$. Differences between Base and the four different types of perturbation are shown for chemical (b) production and (c) loss. These account for the changes in all runs that include a particular type of perturbation; for example, the bars for $\Delta C C 4.5$ represent the mean of the differences $\Delta C C 4.5-$ Base, $\Delta(\mathrm{CC} 4.5+\mathrm{ODS})-\Delta \mathrm{ODS}$ and $\Delta(\mathrm{CC} 4.5+\mathrm{O} 3$ pre $)-\Delta \mathrm{O} 3$ pre. The range of these calculated means is illustrated by whiskers on each bar.

experiment, $\mathrm{NCP}$ is reduced by $55 \mathrm{Tg}\left(\mathrm{O}_{3}\right) \mathrm{yr}^{-1}$ relative to Base, with $P\left(\mathrm{O}_{x}\right)$ reduced $\left(-104 \mathrm{Tg}\left(\mathrm{O}_{3}\right) \mathrm{yr}^{-1}\right)$ more than $L\left(\mathrm{O}_{x}\right)\left(-49 \mathrm{Tg}\left(\mathrm{O}_{3}\right) \mathrm{yr}^{-1}\right)$. This result is strongly influenced by changes in stratospheric ozone which lead to modifications in tropospheric actinic fluxes and photolysis rates, with subsequent chemical feedbacks in the troposphere. $P\left(\mathrm{O}_{x}\right)$ and $L\left(\mathrm{O}_{x}\right)$ are particularly sensitive to photolysis rates for $\mathrm{NO}_{2}$ to $\mathrm{NO}\left(\mathrm{J}\left(\mathrm{NO}_{2}\right)\right)$ and $\mathrm{O}_{3}$ to $\mathrm{O}\left({ }^{1} \mathrm{D}\right)\left(\mathrm{J}\left(\mathrm{O}_{3}\right)\right)$. With increases in stratospheric ozone (Figs. 1e and 2), $\mathrm{J}\left(\mathrm{O}_{3}\right)$ is strongly reduced, but $\mathrm{J}\left(\mathrm{NO}_{2}\right)$ is largely unaffected. Reductions in $\mathrm{J}\left(\mathrm{O}_{3}\right)$ depress $\mathrm{O}\left({ }^{1} \mathrm{D}\right)$ abundances (not shown), despite increases in tropospheric ozone. The reduction in $\mathrm{O}\left({ }^{1} \mathrm{D}\right)$ mixing ratio is largest in the extratropics and peaks at over $50 \%$ in southern high latitudes, where the stratospheric ozone column is enhanced by $\sim 80 \mathrm{DU}$ in the annual mean (not shown), in contrast to the much smaller change in the tropics (see Fig. 2). With lower $\left[\mathrm{O}\left({ }^{1} \mathrm{D}\right)\right]$, the loss of $\mathrm{O}_{x}$ through $\mathrm{O}\left({ }^{1} \mathrm{D}\right)+\mathrm{H}_{2} \mathrm{O}$ is diminished (Fig. $5 \mathrm{c}$ ). Loss through $\mathrm{HO}_{2}+\mathrm{O}_{3}$ is increased, however, due to the increase in tropospheric ozone abundances. By contrast, $P\left(\mathrm{O}_{x}\right)$ is reduced through two of its three major channels as a result of decreases in ODSs (Fig. 5b). Following changes in stratospheric column ozone, previous studies have shown that the sign of the $\mathrm{HO}_{x}$ response follows that of $\mathrm{J}\left(\mathrm{O}_{3}\right)$ regardless of background $\mathrm{NO}_{x}$ levels (Fuglestvedt et al., 1994); in this 
case, decreases in $\mathrm{HO}_{x}$ in the extratropics (and, to a lesser extent, $\left.\mathrm{CH}_{3} \mathrm{O}_{2}\right)$ drive lower $P\left(\mathrm{O}_{x}\right)$.

Whilst much insight can be gained from analysis of the chemical terms of the $\mathrm{O}_{x}$ budget, these alone cannot explain the overall changes in tropospheric ozone burden for the climate change and ODS experiments. As previously described, changes in STE have an important role alongside modifications to tropospheric chemical processes, and these are discussed in the following section.

\subsection{STE}

\subsubsection{Measures of STE and its influence on the troposphere}

Although several metrics for STE exist (Hsu and Prather, 2014), the common approach of inferring STE from the other three terms of the $\mathrm{O}_{x}$ budget is adopted here. In the Base experiment, STE is calculated to be $360 \mathrm{Tg}\left(\mathrm{O}_{3}\right) \mathrm{yr}^{-1}$. STE may be altered by changes in the residual circulation and two-way mixing (which collectively characterise the BDC) (Plumb, 2002), and in the ozone distribution in the extratropical lower stratosphere.

The transformed Eulerian mean (TEM) residual vertical velocity (Andrews et al., 1987) and the total upward and downward residual mass fluxes across a fixed pressure surface (Rosenlof, 1995) are used as metrics for the stratospheric circulation. Mass fluxes are calculated between all latitudes where there is net upward or downward motion, respectively. The upward mass flux at $70 \mathrm{hPa}$ is used as a measure for the overall strength of the residual circulation (SPARC CCMVal, 2010). The downward mass flux at $100 \mathrm{hPa}$ is used as an indicator for the STE of air, although more accurate measures exist (for a fuller discussion see Rosenlof and Holton, 1993; Holton et al., 1995; Rosenlof, 1995; Yang and Tung, 1996).

The climatological, annual mean upward mass flux at $70 \mathrm{hPa}$ in the Base experiment is $7.9 \times 10^{9} \mathrm{~kg} \mathrm{~s}^{-1}$. For comparison, the ERA-Interim reanalysis data (Dee et al., 2011) and most models within the Chemistry-Climate Model Validation project (CCMVal-2) indicate a value of around $6 \times 10^{9} \mathrm{~kg} \mathrm{~s}^{-1}$ (Butchart et al., 2011); the residual circulation is therefore $\sim 33 \%$ stronger in the UM-UKCA model. Changes in the residual circulation in the single-forcing experiments will be linked qualitatively to changes in STE in Sect. 4.5.2.

While quantifying the global and annual net flux of ozone into the troposphere is useful for understanding changes in the global burden of tropospheric ozone, to study the impacts on the distribution of ozone in the troposphere, we use the stratospheric ozone tracer, $\mathrm{O}_{3} \mathrm{~S}$ (see Sect. 2.2). Note that the amount and distribution of $\mathrm{O}_{3} \mathrm{~S}$ in the troposphere depends on its tropospheric lifetime and transport, in addition to transport from the stratosphere. Figure 6 shows the relative contribution of $\mathrm{O}_{3} \mathrm{~S}$ to the annual mean ozone field in

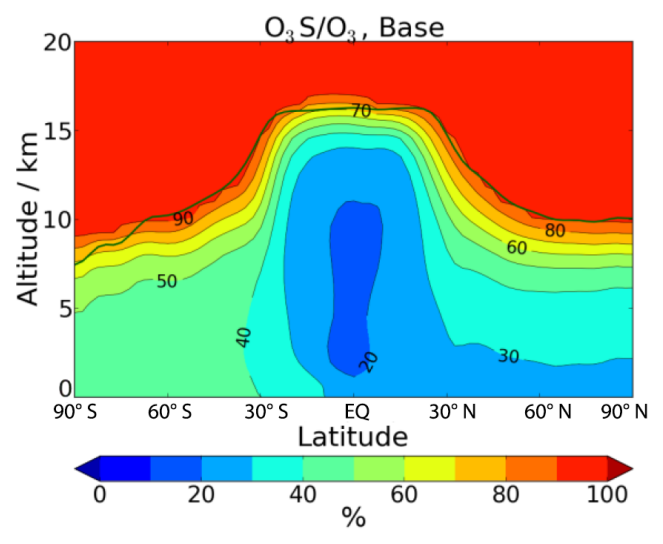

Figure 6. The zonal and annual mean contribution of $\mathrm{O}_{3} \mathrm{~S}$ to ozone in the Base simulation. The solid green line indicates the thermal tropopause of the Base run.

the Base experiment. The contribution is lowest (20\%) in the equatorial region, where upward transport takes place. The contribution is greater in the extratropics, particularly so in the Southern Hemisphere (SH), where other sources of ozone are relatively weak.

\subsubsection{Changes in STE}

The residual circulation, as measured by the upward mass flux at $70 \mathrm{hPa}$, is projected to strengthen under climate change by all climate models (e.g. Butchart et al., 2006, 2010; SPARC CCMVal, 2010; Hardiman et al., 2013). The UM-UKCA model also shows this behaviour: Fig. 7a shows an increase of $10 \%(\triangle \mathrm{CC} 4.5)$ and $27 \%(\triangle \mathrm{CC} 8.5)$ in the annual mean. The latter result is comparable to the CMIP5 multi-model mean increase for the RCP8.5 scenario of $32 \%$ between 2000 and 2100, extrapolated from the linear rate of change found between 2006 and 2099 (Butchart, 2014).

The BDC consists of two distinct branches, commonly referred to as the deep and shallow branches (Plumb, 2002). Both branches strengthen under climate change in these experiments, which is in agreement with other recent studies (Hardiman et al., 2013; Lin and Fu, 2013). The downward mass flux at $100 \mathrm{hPa}$ increases by $11 \%$ in the SH and $21 \%$ in the $\mathrm{NH}$ in $\triangle \mathrm{CC} 4.5$, and by 37 and $42 \%$, respectively, in $\triangle \mathrm{CC} 8.5$ (Fig. $7 \mathrm{~b}$ and c); these are the main contributors to the increases in global STE of 62 and $101 \mathrm{Tg}\left(\mathrm{O}_{3}\right) \mathrm{yr}^{-1}$, respectively. This result is supported by Collins et al. (2003), Zeng and Pyle (2003) and Zeng et al. (2010), who isolated the effects of circulation changes on STE in a future climate.

Figure 8 shows absolute changes in $\mathrm{O}_{3} \mathrm{~S}$ and ozone between Base and selected experiments $(\triangle \mathrm{CC} 8.5, \Delta \mathrm{ODS}$ and $\Delta(\mathrm{CC} 8.5+\mathrm{ODS}))$, as well as changes in tropospheric ozone for comparison. Increases in $\mathrm{O}_{3} \mathrm{~S}$ occur particularly in the subtropical upper troposphere for $\triangle \mathrm{CC} 8.5$ (Fig. 8a), suggesting an increased importance of STE in these regions in a future climate. A strengthened shallow branch of the BDC 

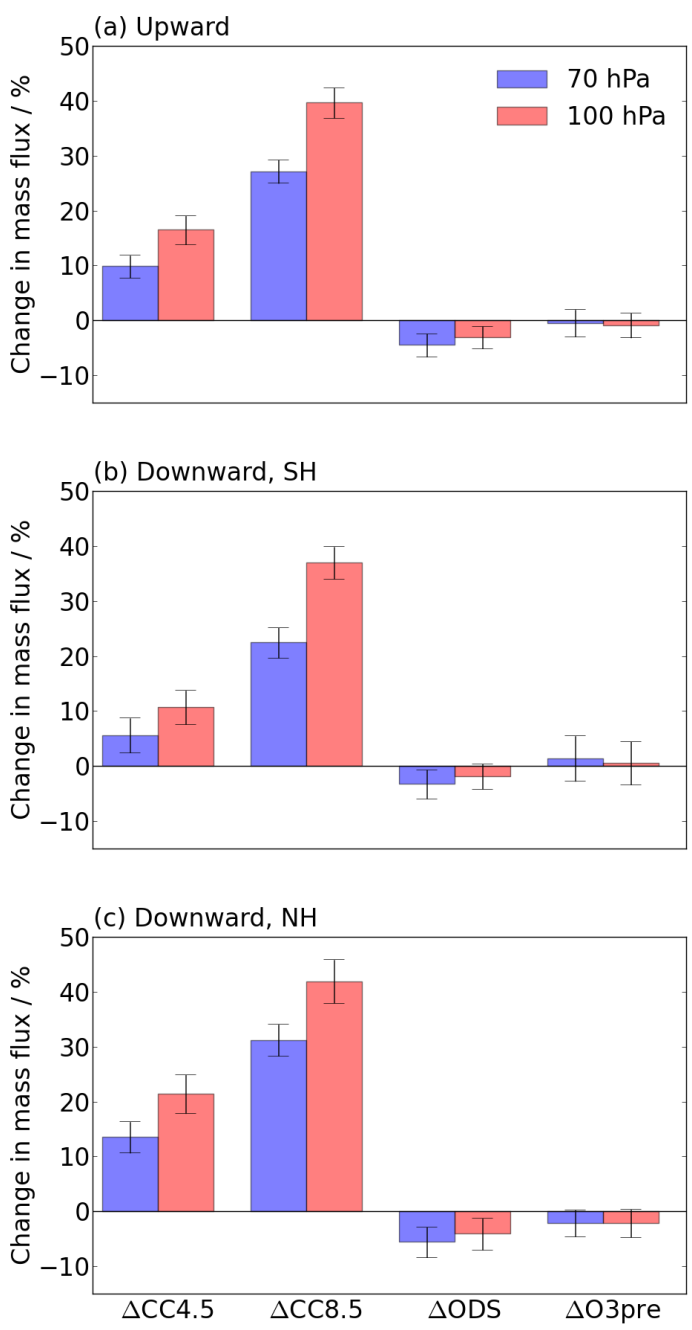

Figure 7. Changes in total (a) upward (b) downward (SH) and (c) downward (NH) mass fluxes at $70 \mathrm{hPa}$ (blue bars) and $100 \mathrm{hPa}$ (red bars) for the single-forcing experiments relative to Base. Error bars indicate the 5-95\% confidence interval, calculated as \pm 1.96 times the standard error in the mean of the change.

contributes to this response. This does not preclude another important contribution from more efficient isentropic stirring across the tropopause (as suggested by the idealised model study of Orbe et al., 2013). This effect may be particularly important for ozone, which has a large concentration gradient across the tropopause.

The peak $\mathrm{O}_{3} \mathrm{~S}$ increase in $\triangle \mathrm{CC} 8.5$ is greater in the $\mathrm{NH}$ subtropics (7 ppbv) than in the SH (5 ppbv). Despite this, the hemispheric asymmetry in the tropospheric ozone change (Fig. 8b) is in the opposite sense, due to a greater contribution from $L \mathrm{NO}_{x}$-produced ozone in the SH. Using a simulation in which climate is allowed to vary according to the RCP8.5 scenario, but in which $L \mathrm{NO}_{x}$ is fixed to Base values (detailed in Banerjee et al., 2014), we deduce that the change in $\mathrm{O}_{3} \mathrm{~S}$ under climate change can be as large as $30 / 50 \%(\mathrm{SH} / \mathrm{NH})$ of the increase in ozone due to increases in $L \mathrm{NO}_{x}$ in the subtropics.

Consistent with Palmeiro et al. (2014), Lin and Fu (2013) and Oberländer et al. (2013), ozone recovery in the $\Delta$ ODS experiment is associated with a weakening of the SH deep branch of the BDC during austral summer. In this model, a weakening of the NH deep branch is also simulated. Concomitantly, the upward mass flux at $70 \mathrm{hPa}$ is reduced by $4.5 \%$ (Fig. 7a). However, the relative mass flux anomalies in the lowermost stratosphere are small, with the downward mass flux at $100 \mathrm{hPa}$ decreasing by only $1.8 / 4.1 \%(\mathrm{SH} / \mathrm{NH})$ (Fig. $7 b$ and c).

While the residual circulation is not strongly affected in the $\triangle$ ODS experiment, STE still increases by $96 \mathrm{Tg}\left(\mathrm{O}_{3}\right) \mathrm{yr}^{-1}$, a change that is approximately equal to that for $\Delta \mathrm{CC} 8.5$. This is attributable to the large increase in extratropical lower stratospheric ozone (Fig. 1e). Increased transport of stratospheric ozone into the extratropical troposphere is evident from the change in $\mathrm{O}_{3} \mathrm{~S}$ for $\triangle$ ODS (Fig. 8c). Greater $\mathrm{O}_{3} \mathrm{~S}$ amounts are particularly prominent in the $\mathrm{NH}$, where, despite the smaller absolute increase in lower stratospheric ozone, the residual circulation is stronger and the net stratosphere to troposphere mass flux of air is larger than in the SH (see also Schoeberl, 2004). The corresponding change in ozone (Fig. 8d) strongly resembles that of $\mathrm{O}_{3} \mathrm{~S}$, suggesting that most of the tropospheric ozone change is driven by increased STE.

Figure 7 shows that the $\Delta O 3$ pre perturbation leads to no significant change in the stratospheric residual circulation; neither is extratropical lower stratospheric ozone greatly affected (Fig. 1g). The amount of ozone entering the troposphere from the stratosphere is therefore similar in the Base and $\triangle \mathrm{O} 3$ pre experiments. The small increase in net STE of $38 \mathrm{Tg}\left(\mathrm{O}_{3}\right) \mathrm{yr}^{-1}$ could instead be due to a reduction in $\mathrm{O}_{x}$ transport from the troposphere into the tropical lower stratosphere, but the effect is small enough to cause no statistically significant change in tropical lower stratospheric ozone amounts (Fig. 1g).

Considering the entire set of experiments, a large range in STE of $360-619 \mathrm{Tg}\left(\mathrm{O}_{3}\right) \mathrm{yr}^{-1}$ is simulated (Fig. 4b), the upper bound of which is found in the $\Delta(\mathrm{CC} 8.5+\mathrm{ODS})$ experiment. Interestingly, climate change and ODSs have their greatest impact on $\mathrm{O}_{3} \mathrm{~S}$ in different regions. Climate change has its largest effect on the subtropical upper troposphere (Fig. 8a), and ODSs on the middle/high latitudes (Fig. 8c). Consequently, there are increases in $\mathrm{O}_{3} \mathrm{~S}$ throughout much of the troposphere in the $\Delta(\mathrm{CC} 8.5+\mathrm{ODS})$ experiment (Fig. 8e). It is notable that, for this experiment, the effect of increased humidity on lowering ozone dominates only in a small region of the lowermost tropical troposphere (Fig. 8f), in contrast to the experiment with climate change alone (Fig. 8b), where the offset is much more widespread.

Within ACCMIP, Young et al. (2013) find that future changes in STE under the RCP scenarios tend to scale (qualitatively) with the magnitude of STE modelled for the present- 

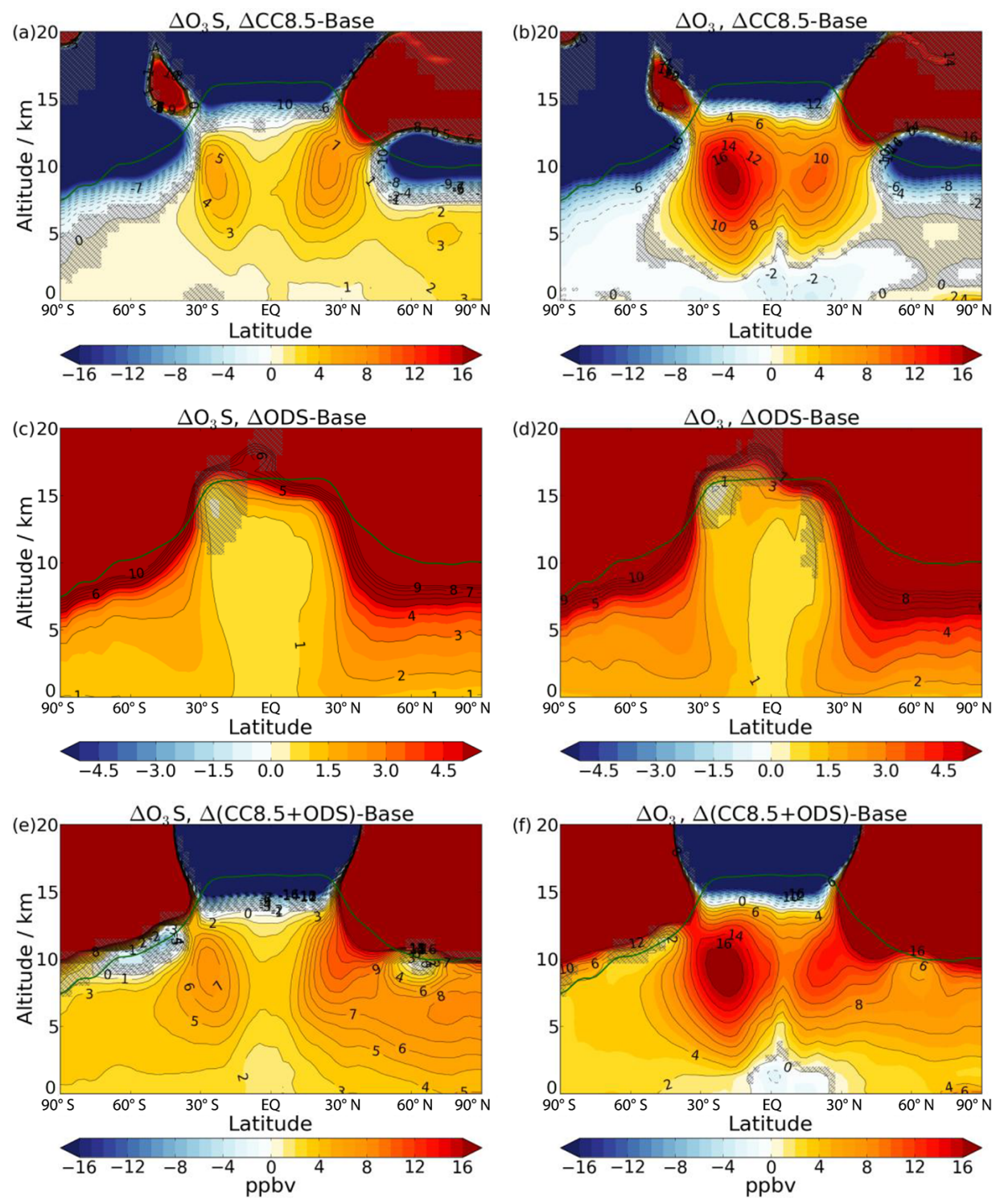

Figure 8. Changes in annual and zonal mean $\mathrm{O}_{3} \mathrm{~S}$ (first column) and ozone (second column) mixing ratios (ppbv) from Base to a selection of experiments, $\Delta \mathrm{CC} 8.5, \Delta \mathrm{ODS}$ and $\Delta(\mathrm{CC} 8.5+\mathrm{ODS})$. The solid green line indicates the thermal tropopause of the Base run. Strong reductions in $\mathrm{O}_{3} \mathrm{~S}$ and ozone occur near the tropopause under climate change because of a lifting of the tropopause, which introduces tropospheric (ozone-poor) air into this region.

day (year 2000). If this relationship holds more generally across models, we might expect future changes in STE for other models to be larger than those found in this study, since the baseline STE in UM-UKCA is on the lower end of the contemporary modelled range. Indeed, increases in STE under climate change in this study (i.e. from a lower baseline) are smaller than found by Kawase et al. (2011) between the years 2005 and 2100 in similar sensitivity experiments. For scenarios which isolate the impact of stratospheric ozone recovery under declining ODS loadings, the absolute changes found here are similar to their results: $96 \mathrm{Tg}\left(\mathrm{O}_{3}\right) \mathrm{yr}^{-1}$ ( $\triangle$ ODS in this study) and $91 \mathrm{Tg}\left(\mathrm{O}_{3}\right) \mathrm{yr}^{-1}$
(Kawase et al., 2011). This suggests that the uncertainty in future changes in STE mostly lies in the effects of climate change and stratospheric circulation.

\subsection{Effects on ozone lifetime}

The lifetime of ozone $\left(\tau_{\mathrm{O}_{3}}\right)$ varies strongly with altitude in the troposphere, ranging from days near the surface, where deposition rates are high, to weeks in the upper troposphere. In particular, longer $\tau_{\mathrm{O}_{3}}$ can amplify the role of ozone as an air pollutant through intercontinental transport (e.g. Wild and Akimoto, 2001), and as a radiative forcing agent. Here, $\tau_{\mathrm{O}_{3}}$ is calculated as the tropospheric ozone burden divided by to- 
tal $\mathrm{O}_{x}$ loss (chemical and deposition). $\tau_{\mathrm{O}_{3}}$ in the Base experiment closely matches the ACCENT and ACCMIP mean values; note that, for this comparison, only the deposition of ozone, and not $\mathrm{O}_{x}$, is considered in the $\tau_{\mathrm{O}_{3}}$ definition (Table 2 , bracketed values). Changes about a baseline $\tau_{\mathrm{O}_{3}}$ of $22.5 \pm 0.1$ days (Table 2 ) as a result of each type of perturbation are now considered.

Figure 9 shows the ozone burden against $\tau_{\mathrm{O}_{3}}$ for all experiments. For the $\Delta \mathrm{O} 3$ pre perturbation, $\tau_{\mathrm{O}_{3}}$ increases by $1.0 \pm 0.1$ days $(4.4 \%)$. In this experiment, the largest reduction in ozone occurs near the surface, where its lifetime is low. Thus, removing ozone in this region further increases $\tau_{\mathrm{O}_{3}}$ (the deposition term of the $\mathrm{O}_{x}$ budget is lower by, on average, $199 \mathrm{Tg}\left(\mathrm{O}_{3}\right) \mathrm{yr}^{-1}$ in all runs which include $\left.\Delta \mathrm{O} 3 \mathrm{pre}\right)$. $\tau_{\mathrm{O}_{3}}$ is also affected by changes in the amount of $\mathrm{HO}_{x}$ and its partitioning. Mitigation of surface $\mathrm{NO}_{x}$ emissions reduces total $\mathrm{HO}_{x}$ (through ozone), which increases $\tau_{\mathrm{O}_{3}}$. The reduction in emissions favours $\mathrm{HO}_{2}$ over $\mathrm{OH}$, which drives a reduction in $\tau_{\mathrm{O}_{3}}$ since loss of ozone to $\mathrm{HO}_{2}$ is greater than to $\mathrm{OH}$ (see Fig. 5a). This is only important in the lowermost troposphere since the $\mathrm{NO}_{x}$ lifetime is short near the surface and the impact on $\tau_{\mathrm{O}_{3}}$ through this mechanism is thus small (Wang and Jacob, 1998). An increase in $\tau_{\mathrm{O}_{3}}$ comes from the decrease in CO (in particular) and NMVOC emissions, which favours $\mathrm{HO}_{x}$ partitioning towards $\mathrm{OH}$, as discussed in Sect. 4.4.

A decrease in $\tau_{\mathrm{O}_{3}}$ of $0.1 \pm 0.1$ days $(0.4 \%)(\Delta \mathrm{CC} 4.5)$ and $1.5 \pm 0.1$ days $(6.7 \%)(\Delta \mathrm{CC} 8.5)$ is found under climate change, predominantly as a result of greater water-vapourinduced loss of ozone. This is counteracted by increases in $L \mathrm{NO}_{x}$ and STE, which increase ozone in the upper troposphere where its lifetime is long. For $\Delta \mathrm{CC} 8.5$, the water vapour effect dominates leading to the largest decrease in $\tau_{\mathrm{O}_{3}}$ within the entire set of experiments (Fig. 9).

In the $\Delta$ ODS experiment, $\tau_{\mathrm{O}_{3}}$ increases by $1.2 \pm 0.1$ days $(5.3 \%)$ as a result of decreases in $\mathrm{O}\left({ }^{1} \mathrm{D}\right), \mathrm{OH}$ and $\mathrm{HO}_{2}$ amounts, especially at middle and high latitudes, as discussed in Sect. 4.4. Enhanced STE augments this effect.

Hence, in terms of $\tau_{\mathrm{O}_{3}}$, the effects of climate change at RCP8.5 oppose those of $\triangle \mathrm{O} 3$ pre, while $\Delta$ ODS enhances them. The largest increase in lifetime of $2.2 \pm 0.1$ days is calculated for $\Delta(\mathrm{ODS}+\mathrm{O} 3 \mathrm{pre})$, which outweighs the decrease in $\Delta$ CC8.5 (1.5 \pm 0.1 days). The colour-coded arrows in Fig. 9 denote the changes in $\tau_{\mathrm{O}_{3}}$ when a particular type of perturbation is added, either in isolation or in combination. The fact that all arrows for a particular type of perturbation (i.e. those of a particular colour) follow approximately the same path indicates that the changes are linearly additive.

\subsection{Tropospheric additivity}

We now consider the additivity in the tropospheric ozone response for the combined-forcing experiments. Figure 10 compares modelled values of NCP, STE and the ozone burden for the combined-forcing experiments with those ex-

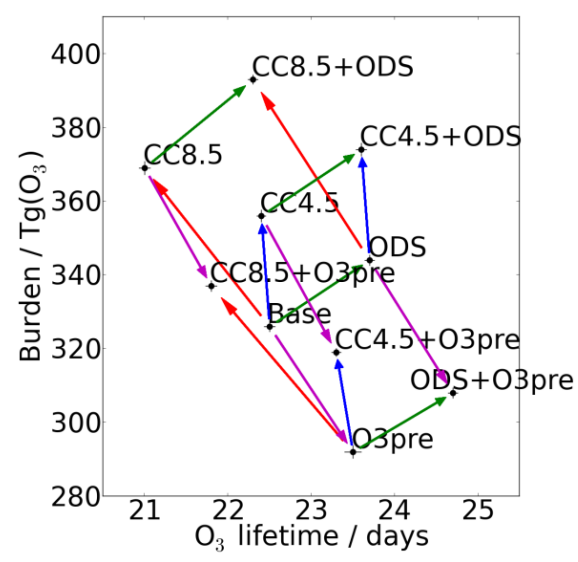

Figure 9. Tropospheric ozone burden against the ozone lifetime. Arrows indicate the impact of climate change at RCP4.5 (blue) and RCP8.5 (red), reduced ODS loadings (green) and reduced ozone precursor emissions (magenta). Error bars indicate the 5-95\% confidence interval, calculated as \pm 1.96 times the standard error in the mean.
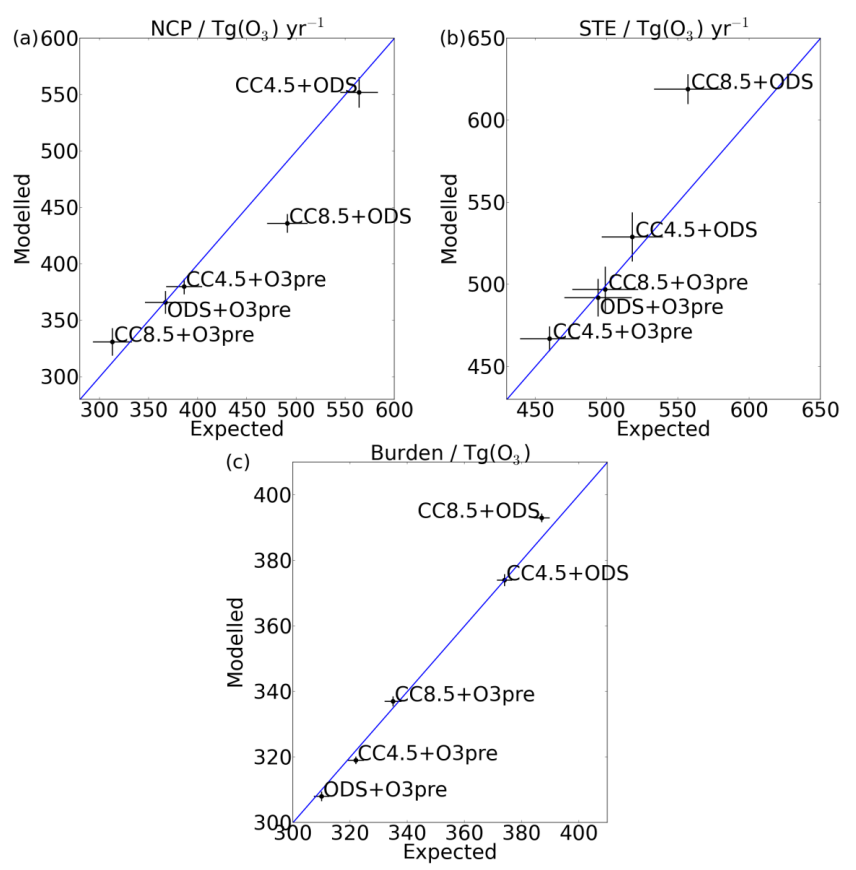

Figure 10. Correlations in (a) NCP, (b) STE and (c) the ozone burden between the combined-forcing experiments and those expected from a linear addition of changes in the single-forcing experiments relative to Base. The $1: 1$ lines are drawn in blue. Error bars indicate the $5-95 \%$ confidence interval calculated as \pm 1.96 times the standard error in the mean.

pected from a linear addition of changes in the respective single-forcing experiments. It is evident that, generally, the changes match those expected assuming additivity.

The $\Delta(C C 8.5+O D S)$ simulation raises the only significant exception. The increase in STE in $\Delta($ CC $8.5+$ ODS $)$ 
is $62 \mathrm{Tg}\left(\mathrm{O}_{3}\right) \mathrm{yr}^{-1}$ greater than the sum of the increases in the $\triangle \mathrm{CC} 8.5$ and $\triangle$ ODS experiments (Fig. 10b). Consistent with this, only $\Delta(\mathrm{CC} 8.5+\mathrm{ODS})$ exhibits a non-additivity in changes in $\mathrm{O}_{3} \mathrm{~S}$ (Fig. 11), which extends from the stratosphere into the troposphere in the $\mathrm{SH}$ and, to a lesser extent, in the NH. This is qualitatively expected since an increase in the strength of the stratospheric circulation (due to climate change) under greater background ozone (due to reduced ODS amounts) leads to a greater increase in STE than expected from the sum of the two separate effects. The impact is largest in the $\mathrm{SH}$, where increases in lower stratospheric ozone are largest.

The non-additive change in ozone in the SH lower stratosphere for this experiment (Fig. 3b) might further contribute to the non-additive change in STE, although we cannot verify such an assumption due to the relevant diagnostics not being available and further sensitivity tests would be required.

Non-additivity in $\triangle(C C 8.5+\mathrm{ODS})$ is also evident in $\mathrm{NCP}$ (Fig. 10a), which is found to be $55 \mathrm{Tg}\left(\mathrm{O}_{3}\right) \mathrm{yr}^{-1}$ less than expected. The response is driven by chemical loss rather than production: greater loss occurs directly as a result of STE-derived increases in ozone (relative to the additive response). To a great extent, the larger loss counters increased STE, such that the change in the global ozone burden for $\Delta$ (CC8.5+ODS) (Fig. 10c) is close to the expected response, demonstrating the strong buffering that takes place in response to increases in tropospheric ozone.

\section{Conclusions}

This study has explored the impacts of future climate change, reductions in ozone-depleting substances (ODSs) and in nonmethane ozone precursor emissions on global ozone and, in particular, on the tropospheric budget of odd oxygen $\left(\mathrm{O}_{x}\right)$. Time-slice experiments representing conditions for the years 2000 and 2100 were performed with the UM-UKCA chemistry-climate model (CCM), in a configuration that contains a comprehensive description of both stratospheric and tropospheric chemistry. This allowed an investigation of the consequences of future changes in stratospheric chemistry and dynamics for the tropospheric $\mathrm{O}_{x}$ budget.

The principal results regarding the stratosphere are as follows:

1. Changes in ozone and temperature are in qualitative agreement with previous literature.

2. For simulations in which two types of perturbation are combined, changes in ozone can generally be reproduced by the sum of changes in the appropriate singleforcing experiments. The only exception arises when combining a large climate forcing (RCP8.5) with the effects of ODSs, for which there is detectable nonadditivity in the upper stratosphere and Southern Hemisphere lower stratosphere.

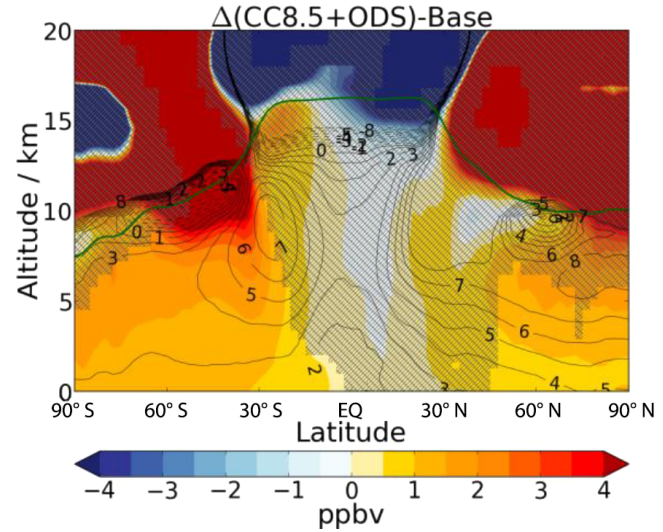

Figure 11. As for Fig. 3, but showing the change in $\mathrm{O}_{3} \mathrm{~S}$ (ppbv, contours) from Base to $\Delta(\mathrm{CC} 8.5+\mathrm{ODS})$ as well as the deviation from additivity (shading) of the response. Areas where the shading is not significant at the $95 \%$ level according to a two-tailed Student's $t$ test are hatched out. The solid green line indicates the thermal tropopause of the Base run.

The principal results regarding the troposphere are the following:

1. The global tropospheric ozone burden decreases with projected reductions in ozone precursor emissions as part of air quality controls, but this effect is opposed by future changes in climate and ODSs; some combination of these processes will determine future changes in tropospheric oxidising capacity and background surface ozone.

2. Increases in stratosphere-troposphere exchange (STE) of $\mathrm{O}_{x}$ primarily result from a strengthened BrewerDobson circulation under climate change and from increases in lower stratospheric ozone abundances under reduced ODSs.

3. The increases in STE act to increase ozone most in the subtropical (climate change) and extratropical (ODS changes) upper troposphere; this should have implications for the climate feedback since the upper troposphere is a key region for ozone as a radiative forcing agent.

4. The enhancements in STE offset concomitant reductions in net chemical production and act to increase the global tropospheric ozone burdens under climate change and reduced ODSs.

5. The global tropospheric lifetime of ozone is enhanced under lower ozone precursor emissions and ODSs; this is opposed by a decrease under climate change at RCP8.5. Essentially no change is found for climate change at RCP4.5. 
6. Changes in the tropospheric $\mathrm{O}_{x}$ budget terms when combining two types of perturbation can generally be reproduced by summing the effects of the separate perturbations. Combining changes in climate (RCP8.5) and ODSs leads to a non-additive change in STE, but the effect on the ozone burden is strongly buffered.

The sensitivity tests in this study have investigated the effects of some, but not all, of the key drivers of ozone under selected scenarios. For example, the future evolution of methane is highly uncertain and its chemical effects have not been examined here. CCM studies that have imposed increases in methane according to the RCP scenarios show large increases in tropospheric ozone, particularly at RCP8.5, which would greatly oppose the effects of emission controls on global, tropospheric ozone (e.g. Young et al., 2013; Revell et al., 2015).

The base climate state, climate sensitivity (incorporated here through the imposed sea surface temperatures), chemical complexity and parameterisations of processes such as lightning $\mathrm{NO}_{x}$ emissions may all contribute to inter-model differences and uncertainties in projections of future ozone. However, although the quantitative results of this study are likely to be specific to UM-UKCA, the significance of the stratosphere in determining future changes in tropospheric ozone through STE is clear. The results therefore emphasise the need for a good representation of STE in CCMs to simulate future tropospheric ozone. While models with simplified stratospheric ozone chemistry are unlikely to represent STE accurately (Olsen et al., 2013), this study achieves greater fidelity in its representation through the use of a CCM which contains a relatively sophisticated description of stratospheric and tropospheric chemistry and dynamics. Nonetheless, better constraints on observed estimates of STE are required to deduce whether modelled values are realistic; it is hoped that, with continued satellite observations of ozone in the upper stratosphere-lower stratosphere (e.g. Livesey et al., 2008), this uncertainty can be reduced.

Acknowledgements. We thank the ERC for support under the ACCI project, project no. 267760. A. C. Maycock was supported by a postdoctoral fellowship from the AXA Research Fund. A. T. Archibald was supported by a fellowship from the Herchel Smith Foundation. This work made use of the facilities of HECToR, the UK's national high-performance computing service, which was provided by UoE HPCx Ltd at the University of Edinburgh, Cray Inc and NAG Ltd, and funded by the Office of Science and Technology through EPSRC's High End Computing Programme. This work also used the ARCHER UK National Supercomputing Service (http://www.archer.ac.uk).

Edited by: J. West

\section{References}

Andrews, D. G., Holton, J. R., and Leovy, C. B.: Middle Atmosphere Dynamics, Academic Press, San Diego, USA, 1987.

Andrews, T., Gregory, J. M., Webb, M. J., and Taylor, K. E.: Forcing, feedbacks and climate sensitivity in CMIP5 coupled atmosphere-ocean climate models, Geophys. Res. Lett., 39, L09712, doi:10.1029/2012GL051607, 2012.

Austin, J., Scinocca, J., Plummer, D., Oman, L., Waugh, D., Akiyoshi, H., Bekki, S., Braesicke, P., Butchart, N., Chipperfield, M., Cugnet, D., Dameris, M., Dhomse, S., Eyring, V., Frith, S., Garcia, R. R., Garny, H., Gettelman, A., Hardiman, S. C., Kinnison, D., Lamarque, J. F., Mancini, E., Marchand, M., Michou, M., Morgenstern, O., Nakamura, T., Pawson, S., Pitari, G., Pyle, J., Rozanov, E., Shepherd, T. G., Shibata, K., Teyssèdre, H., Wilson, R. J., and Yamashita, Y.: Decline and recovery of total column ozone using a multimodel time series analysis, J. Geophys. Res.-Atmos., 115, D00M10, doi:10.1029/2010JD013857, 2010.

Banerjee, A., Archibald, A. T., Maycock, A. C., Telford, P., Abraham, N. L., Yang, X., Braesicke, P., and Pyle, J. A.: Lightning $\mathrm{NO}_{x}$, a key chemistry-climate interaction: impacts of future climate change and consequences for tropospheric oxidising capacity, Atmos. Chem. Phys., 14, 9871-9881, doi:10.5194/acp-149871-2014, 2014.

Butchart, N.: The Brewer-Dobson circulation, Rev. Geophys., 52, 157-184, doi:10.1002/2013RG000448, 2014.

Butchart, N., Scaife, A. A., Bourqui, M., Grandpré, J., Hare, S. H. E., Kettleborough, J., Langematz, U., Manzini, E., Sassi, F., Shibata, K., Shindell, D., and Sigmond, M.: Simulations of anthropogenic change in the strength of the Brewer-Dobson circulation, Clim. Dynam., 27, 727-741, doi:10.1007/s00382-0060162-4, 2006.

Butchart, N., Cionni, I., Eyring, V., Shepherd, T. G., Waugh, D. W., Akiyoshi, H., Austin, J., Brühl, C., Chipperfield, M. P., Cordero, E., Dameris, M., Deckert, R., Dhomse, S., Frith, S. M., Garcia, R. R., Gettelman, A., Giorgetta, M. A., Kinnison, D. E., Li, F., Mancini, E., Mclandress, C., Pawson, S., Pitari, G., Plummer, D. A., Rozanov, E., Sassi, F., Scinocca, J. F., Shibata, K., Steil, B., and Tian, W.: Chemistry-climate model simulations of twentyfirst century stratospheric climate and circulation changes, J. Climate, 23, 5349-5374, doi:10.1175/2010JCLI3404.1, 2010.

Butchart, N., Charlton-Perez, A. J., Cionni, I., Hardiman, S. C., Haynes, P. H., Krüger, K., Kushner, P. J., Newman, P. A., Osprey, S. M., Perlwitz, J., Sigmond, M., Wang, L., Akiyoshi, H., Austin, J., Bekki, S., Baumgaertner, A., Braesicke, P., Brühl, C., Chipperfield, M., Dameris, M., Dhomse, S., Eyring, V., Garcia, R., Garny, H., Jöckel, P., Lamarque, J.-F., Marchand, M., Michou, M., Morgenstern, O., Nakamura, T., Pawson, S., Plummer, D., Pyle, J., Rozanov, E., Scinocca, J., Shepherd, T. G., Shibata, K., Smale, D., Teyssèdre, H., Tian, W., Waugh, D., and Yamashita, Y.: Multimodel climate and variability of the stratosphere, J. Geophys. Res.-Atmos., 116, D05102, doi:10.1029/2010JD014995, 2011.

Chipperfield, M. P. and Feng, W.: Comment on: Stratospheric Ozone Depletion at northern mid-latitudes in the 21 st century: The importance of future concentrations of greenhouse gases nitrous oxide and methane, Geophys. Res. Lett., 30, 1389, doi:10.1029/2002GL016353, 2003.

Collins, W. J., Derwent, R. G., Garnier, B., Johnson, C. E., Sanderson, M. G., and Stevenson, D. S.: Effect of stratosphere- 
troposphere exchange on the future tropospheric ozone trend, J. Geophys. Res.-Atmos., 108, 8528, doi:10.1029/2002JD002617, 2003

Dee, D. P., Uppala, S. M., Simmons, A. J., Berrisford, P., Poli, P., Kobayashi, S., Andrae, U., Balmaseda, M. A., Balsamo, G., Bauer, P., Bechtold, P., Beljaars, A. C. M., van de Berg, L., Bidlot, J., Bormann, N., Delsol, C., Dragani, R., Fuentes, M., Geer, A. J., Haimberger, L., Healy, S. B., Hersbach, H., Hólm, E. V., Isaksen, L., Kållberg, P., Köhler, M., Matricardi, M., Mcnally, A. P., Monge-Sanz, B. M., Morcrette, J. J., Park, B. K., Peubey, C., de Rosnay, P., Tavolato, C., Thépaut, J. N., and Vitart, F.: The ERA-Interim reanalysis: Configuration and performance of the data assimilation system, Q. J. Roy. Meteor. Soc., 137, 553-597, doi:10.1002/qj.828, 2011.

Dessens, O., Zeng, G., Warwick, N., and Pyle, J.: Short-lived bromine compounds in the lower stratosphere; impact of climate change on ozone, Atmos. Sci. Lett., 10, 201-206, doi:10.1002/asl.236, 2009.

Eyring, V., Arblaster, J. M., Cionni, I., Sedláček, J., Perlwitz, J., Young, P. J., Bekki, S., Bergmann, D., Cameron-Smith, P., Collins, W. J., Faluvegi, G., Gottschaldt, K.-D., Horowitz, L. W., Kinnison, D. E., Lamarque, J.-F., Marsh, D. R., Saint-Martin, D., Shindell, D. T., Sudo, K., Szopa, S., and Watanabe, S.: Long-term ozone changes and associated climate impacts in CMIP5 simulations, J. Geophys. Res.-Atmos., 118, 5029-5060, doi:10.1002/jgrd.50316, 2013.

Fels, S. B., Mahlman, J. D., Schwarzkopf, M. D., and Sinclair, R. W.: Stratospheric Sensitivity to Perturbations in Ozone and Carbon Dioxide: Radiative and Dynamical Response, J. Atmos. Sci., 37, 2265-2297, doi:10.1175/15200469(1980)037<2265:SSTPIO>2.0.CO;2, 1980.

Fiore, A. M., Naik, V., Spracklen, D. V., Steiner, A., Unger, N., Prather, M., Bergmann, D., Cameron-Smith, P. J., Cionni, I., Collins, W. J., Dalsøren, S., Eyring, V., Folberth, G. A., Ginoux, P., Horowitz, L. W., Josse, B., Lamarque, J.-F., MacKenzie, I. A., Nagashima, T., O’Connor, F. M., Righi, M., Rumbold, S. T., Shindell, D. T., Skeie, R. B., Sudo, K., Szopa, S., Takemura, T., and Zeng, G.: Global air quality and climate, Chem. Soc. Rev., 41, 6663-6683, doi:10.1039/c2cs35095e, 2012.

Fleming, E. L., Jackman, C. H., Stolarski, R. S., and Douglass, A. R.: A model study of the impact of source gas changes on the stratosphere for 1850-2100, Atmos. Chem. Phys., 11, 85158541, doi:10.5194/acp-11-8515-2011, 2011.

Fuglestvedt, J.: Climatic forcing of nitrogen oxides through changes in tropospheric ozone and methane; global 3-D model studies, Atmos. Environ., 33, 961-977, doi:10.1016/S13522310(98)00217-9, 1999

Fuglestvedt, J. S., Johnson, J. E., and Isaksen, I. S. A.: Effects of reductions in stratospheric ozone on tropospheric chemistry through changes in photolysis rates, Tellus, 46B, 172-192, doi:10.1034/j.1600-0889.1992.t01-3-00001.x-i1, 1994.

Gettelman, A., Holton, J. R., and Rosenlof, K. H.: Mass fluxes of $\mathrm{O}_{3}, \mathrm{CH}_{4}, \mathrm{~N}_{2} \mathrm{O}$ and $\mathrm{CF}_{2} \mathrm{Cl}_{2}$ in the lower stratosphere calculated from observational data, J. Geophys. Res.-Atmos., 102, 1914919159, doi:10.1029/97JD01014, 1997.

Grewe, V.: Impact of Lightning on Air Chemistry and Climate, in: Lightning: Principles, Instruments and Applications, Review of Modern Lightning Research, edited by: Betz, H. D., Schumann, U., and Laroche, P., Springer Netherlands, available at: http://link.springer.com/book/10.1007/978-1-4020-9079-0 (last access: 28 February 2016), 2009.

HadGEM2 Development Team: Martin, G. M., Bellouin, N., Collins, W. J., Culverwell, I. D., Halloran, P. R., Hardiman, S. C., Hinton, T. J., Jones, C. D., McDonald, R. E., McLaren, A. J., O’Connor, F. M., Roberts, M. J., Rodriguez, J. M., Woodward, S., Best, M. J., Brooks, M. E., Brown, A. R., Butchart, N., Dearden, C., Derbyshire, S. H., Dharssi, I., Doutriaux-Boucher, M., Edwards, J. M., Falloon, P. D., Gedney, N., Gray, L. J., Hewitt, H. T., Hobson, M., Huddleston, M. R., Hughes, J., Ineson, S., Ingram, W. J., James, P. M., Johns, T. C., Johnson, C. E., Jones, A., Jones, C. P., Joshi, M. M., Keen, A. B., Liddicoat, S., Lock, A. P., Maidens, A. V., Manners, J. C., Milton, S. F., Rae, J. G. L., Ridley, J. K., Sellar, A., Senior, C. A., Totterdell, I. J., Verhoef, A., Vidale, P. L., and Wiltshire, A.: The HadGEM2 family of Met Office Unified Model climate configurations, Geosci. Model Dev., 4, 723-757, doi:10.5194/gmd-4-723-2011, 2011.

Haigh, J. D. and Pyle, J. A.: Ozone perturbation experiments in a two-dimensional circulation model, Q. J. Roy. Meteor. Soc., 108, 551-574, doi:10.1002/qj.49710845705, 1982.

Hardiman, S. C., Butchart, N., and Calvo, N.: The morphology of the Brewer-Dobson circulation and its response to climate change in CMIP5 simulations, Q. J. Roy. Meteor. Soc., 140, 1958-1965, doi:10.1002/qj.2258, 2013.

Hauglustaine, D. A., Lathière, J., Szopa, S., and Folberth, G. A.: Future tropospheric ozone simulated with a climatechemistry-biosphere model, Geophys. Res. Lett., 32, L24807, doi:10.1029/2005GL024031, 2005.

Holton, J. R., Haynes, P. H., McIntyre, M. E., Douglass, A. R., Rood, R. B., and Pfister, L.: Stratosphere-troposphere exchange, Rev. Geophys., 33, 403-439, doi:10.1029/95RG02097, 1995.

Hossaini, R., Chipperfield, M. P., Dhomse, S., Ordóñez, C., Saiz-Lopez, A., Abraham, N. L., Archibald, A., Braesicke, P., Telford, P., Warwick, N., Yang, X., and Pyle, J.: Modelling future changes to the stratospheric source gas injection of biogenic bromocarbons, Geophys. Res. Lett., 39, L20813, doi:10.1029/2012GL053401, 2012.

Hsu, J. and Prather, M. J.: Is the residual vertical velocity a good proxy for stratosphere-troposphere exchange of ozone?, Geophys. Res. Lett., 41, 9024-9032, doi:10.1002/2014GL061994, 2014.

IPCC: Climate Change 2001: The Scientific Basis. Contribution of Working Group I to the Third Assessment Report of the Intergovernmental Panel on Climate Change, edited by: Houghton, J. T., Ding, Y., Griggs, D. J., Noguer, M., van der Linden, P. J., Dai, X., Maskell, K., and Johnson, C. A., Cambridge University Press, Cambridge, UK and New York, NY, USA, 2001.

IPCC: Climate Change 2013: The Physical Science Basis. Contribution of Working Group I to the Fifth Assessment Report of the Intergovernmental Panel on Climate Change, edited by: Stocker, T. F., Qin, D., Plattner, G.-K., Tignor, M., Allen, S. K., Boschung, J., Nauels, A., Xia, Y., Bex, V., and Midgley, P. M., Cambridge University Press, Cambridge, UK and New York, NY, USA, 2013.

Isaksen, I. S. A. and Hov, Ø.: Calculation of trends in the tropospheric concentration of $\mathrm{O}_{3}, \mathrm{OH}, \mathrm{CO}, \mathrm{CH}_{4}$ and $\mathrm{NO}_{x}$, Tellus $\mathrm{B}$, 39B, 271-285, doi:10.1111/j.1600-0889.1987.tb00099.x, 1987.

Johnson, C. E., Collins, W. J., Stevenson, D. S., and Derwent, R. G.: Relative roles of climate and emissions changes on future 
tropospheric oxidant concentrations, J. Geophys. Res.-Atmos., 104, 18631-18645, doi:10.1029/1999JD900204, 1999.

Jonsson, A. I., de Grandpré, J., Fomichev, V. I., McConnell, J. C., and Beagley, S. R.: Doubled $\mathrm{CO}_{2}$-induced cooling in the middle atmosphere: Photochemical analysis of the ozone radiative feedback, J. Geophys. Res.-Atmos., 109, D24103, doi:10.1029/2004JD005093, 2004.

Kawase, H., Nagashima, T., Sudo, K., and Nozawa, T.: Future changes in tropospheric ozone under Representative Concentration Pathways (RCPs), Geophys. Res. Lett., 38, L05801, doi:10.1029/2010GL046402, 2011.

Lamarque, J.-F., Shindell, D. T., Josse, B., Young, P. J., Cionni, I., Eyring, V., Bergmann, D., Cameron-Smith, P., Collins, W. J., Doherty, R., Dalsoren, S., Faluvegi, G., Folberth, G., Ghan, S. J., Horowitz, L. W., Lee, Y. H., MacKenzie, I. A., Nagashima, T., Naik, V., Plummer, D., Righi, M., Rumbold, S. T., Schulz, M., Skeie, R. B., Stevenson, D. S., Strode, S., Sudo, K., Szopa, S., Voulgarakis, A., and Zeng, G.: The Atmospheric Chemistry and Climate Model Intercomparison Project (ACCMIP): overview and description of models, simulations and climate diagnostics, Geosci. Model Dev., 6, 179-206, doi:10.5194/gmd-6-179-2013, 2013.

Lin, M., Fiore, A. M., Cooper, O. R., Horowitz, L. W., Langford, A. O., Levy, H., Johnson, B. J., Naik, V., Oltmans, S. J., and Senff, C. J.: Springtime high surface ozone events over the western United States: Quantifying the role of stratospheric intrusions, J. Geophys. Res.-Atmos., 117, D00V22, doi:10.1029/2012JD018151, 2012.

Lin, P. and Fu, Q.: Changes in various branches of the Brewer-Dobson circulation from an ensemble of chemistry climate models, J. Geophys. Res.-Atmos., 118, 73-84, doi:10.1029/2012JD018813, 2013.

Livesey, N. J., Filipiak, M. J., Froidevaux, L., Read, W. G., Lambert, A., Santee, M. L., Jiang, J. H., Pumphrey, H. C., Waters, J. W., Cofield, R. E., Cuddy, D. T., Daffer, W. H., Drouin, B. J., Fuller, R. A., Jarnot, R. F., Jiang, Y. B., Knosp, B. W., Li, Q. B., Perun, V. S., Schwartz, M. J., Snyder, W. V., Stek, P. C., Thurstans, R. P., Wagner, P. A., Avery, M., Browell, E. V., Cammas, J.-P., Christensen, L. E., Diskin, G. S., Gao, R.-S., Jost, H.J., Loewenstein, M., Lopez, J. D., Nedelec, P., Osterman, G. B., Sachse, G. W., and Webster, C. R.: Validation of Aura Microwave Limb Sounder $\mathrm{O}_{3}$ and $\mathrm{CO}$ observations in the upper troposphere and lower stratosphere, J. Geophys. Res.-Atmos., 113, D15S02, doi:10.1029/2007JD008805, 2008.

McLandress, C. and Shepherd, T. G.: Simulated anthropogenic changes in the Brewer-Dobson circulation, including its extension to high latitudes, J. Climate, 22, 1516-1540, doi:10.1175/2008JCLI2679.1, 2009.

McLandress, C., Perlwitz, J., and Shepherd, T. G.: Comment on "Tropospheric temperature response to stratospheric ozone recovery in the 21 st century" by Hu et al. (2011), Atmos. Chem. Phys., 12, 2533-2540, doi:10.5194/acp-12-2533-2012, 2012.

Meinshausen, M., Smith, S. J., Calvin, K., Daniel, J. S., Kainuma, M. L. T., Lamarque, J., Matsumoto, K., Montzka, S. A., Raper, S. C. B., Riahi, K., Thomson, A., Velders, G. J. M., and van Vuuren, D. P. P.: The RCP greenhouse gas concentrations and their extensions from 1765 to 2300 , Clim. Change, 109, 213241, doi:10.1007/s10584-011-0156-z, 2011.
Meul, S., Langematz, U., Oberländer, S., Garny, H., and Jöckel, P.: Chemical contribution to future tropical ozone change in the lower stratosphere, Atmos. Chem. Phys., 14, 2959-2971, doi:10.5194/acp-14-2959-2014, 2014.

Meul, S., Oberländer-Hayn, S., Abalichin, J., and Langematz, U.: Nonlinear response of modelled stratospheric ozone to changes in greenhouse gases and ozone depleting substances in the recent past, Atmos. Chem. Phys., 15, 6897-6911, doi:10.5194/acp-156897-2015, 2015.

Morgenstern, O., Braesicke, P., O'Connor, F. M., Bushell, A. C., Johnson, C. E., Osprey, S. M., and Pyle, J. A.: Evaluation of the new UKCA climate-composition model - Part 1: The stratosphere, Geosci. Model Dev., 2, 43-57, doi:10.5194/gmd-2-432009, 2009.

Morgenstern, O., Zeng, G., Abraham, N. L., Telford, P. J., Braesicke, P., Pyle, J. A., Hardiman, S. C., O’Connor, F. M., and Johnson, C. E.: Impacts of climate change, ozone recovery, and increasing methane on surface ozone and the tropospheric oxidizing capacity, J. Geophys. Res.-Atmos., 118, 1028-1041, doi:10.1029/2012JD018382, 2013.

Naik, V., Voulgarakis, A., Fiore, A. M., Horowitz, L. W., Lamarque, J.-F., Lin, M., Prather, M. J., Young, P. J., Bergmann, D., Cameron-Smith, P. J., Cionni, I., Collins, W. J., Dalsøren, S. B., Doherty, R., Eyring, V., Faluvegi, G., Folberth, G. A., Josse, B., Lee, Y. H., MacKenzie, I. A., Nagashima, T., van Noije, T. P. C., Plummer, D. A., Righi, M., Rumbold, S. T., Skeie, R., Shindell, D. T., Stevenson, D. S., Strode, S., Sudo, K., Szopa, S., and Zeng, G.: Preindustrial to present-day changes in tropospheric hydroxyl radical and methane lifetime from the Atmospheric Chemistry and Climate Model Intercomparison Project (ACCMIP), Atmos. Chem. Phys., 13, 5277-5298, doi:10.5194/acp-13-5277-2013, 2013.

Oberländer, S., Langematz, U., and Meul, S.: Unraveling impact factors for future changes in the Brewer-Dobson circulation, J. Geophys. Res.-Atmos., 118, 10296-10312, doi:10.1002/jgrd.50775, 2013.

O'Connor, F. M., Johnson, C. E., Morgenstern, O., Abraham, N. L., Braesicke, P., Dalvi, M., Folberth, G. A., Sanderson, M. G., Telford, P. J., Voulgarakis, A., Young, P. J., Zeng, G., Collins, W. J., and Pyle, J. A.: Evaluation of the new UKCA climatecomposition model - Part 2: The Troposphere, Geosci. Model Dev., 7, 41-91, doi:10.5194/gmd-7-41-2014, 2014.

Olsen, M. A., Douglass, A. R., and Kaplan, T. B.: Variability of extratropical ozone stratosphere-troposphere exchange using microwave limb sounder observations, J. Geophys. Res.-Atmos., 118, 1090-1099, doi:10.1029/2012JD018465, 2013.

Olsen, S. C., Mclinden, C. A., and Prather, M. J.: Stratospheric $\mathrm{N}_{2} \mathrm{O}-\mathrm{NO}_{y}$ system: Testing uncertainties in a three-dimensional framework, J. Geophys. Res.-Atmos., 106, 28771-28784, 2001.

Orbe, C., Holzer, M., Polvani, L. M., and Waugh, D.: Air-mass origin as a diagnostic of tropospheric transport, J. Geophys. Res.Atmos., 118, 1459-1470, doi:10.1002/jgrd.50133, 2013.

Pacifico, F., Harrison, S. P., Jones, C. D., and Sitch, S.: Isoprene emissions and climate, Atmos. Environ., 43, 6121-6135, doi:10.1016/j.atmosenv.2009.09.002, 2009.

Palmeiro, F. M., Calvo, N., and Garcia, R. R.: Future changes in the Brewer-Dobson circulation under different greenhouse gas concentrations in WACCM4, J. Atmos. Sci., 71, 2962-2975, doi:10.1175/JAS-D-13-0289.1, 2014. 
Plumb, R. A.: Large-scale Stratospheric Transport Processes, J. Meteorol. Soc. Jpn., 80, 793-809, doi:10.2151/jmsj.80.793, 2002.

Portmann, R. W. and Solomon, S.: Indirect radiative forcing of the ozone layer during the 21 st century, Geophys. Res. Lett., 34, 1-5, doi:10.1029/2006GL028252, 2007.

Portmann, R. W., Daniel, J. S., and Ravishankara, A. R.: Stratospheric ozone depletion due to nitrous oxide: influences of other gases, Philos. T. Roy. Soc. B, 367, 1256-1264, doi:10.1098/rstb.2011.0377, 2012.

Prather, M. J., Zhu, X., Tang, Q., Hsu, J., and Neu, J. L.: An atmospheric chemist in search of the tropopause, J. Geophys. Res.Atmos., 116, D04306, doi:10.1029/2010JD014939, 2011.

Price, C. and Rind, D.: A simple lightning parameterization for calculating global lightning distributions, J. Geophys. Res.-Atmos., 97, 9919-9933, 1992.

Price, C. G. and Rind, D.: Modeling global lightning distributions in a general circulation model, Mon. Weather Rev., 122, 19301939, 1994.

Randeniya, L. K., Vohralik, P. F., and Plumb, I. C.: Stratospheric ozone depletion at northern mid latitudes in the 21st century: The importance of future concentrations of greenhouse gases nitrous oxide and methane, Geophys. Res. Lett., 29, 1051, doi:10.1029/2001GL014295, 2002.

Revell, L. E., Bodeker, G. E., Huck, P. E., Williamson, B. E., and Rozanov, E.: The sensitivity of stratospheric ozone changes through the 21 st century to $\mathrm{N}_{2} \mathrm{O}$ and $\mathrm{CH}_{4}$, Atmos. Chem. Phys., 12, 11309-11317, doi:10.5194/acp-12-11309-2012, 2012.

Revell, L. E., Tummon, F., Stenke, A., Sukhodolov, T., Coulon, A., Rozanov, E., Garny, H., Grewe, V., and Peter, T.: Drivers of the tropospheric ozone budget throughout the 21 st century under the medium-high climate scenario RCP 6.0, Atmos. Chem. Phys., 15, 5887-5902, doi:10.5194/acp-15-5887-2015, 2015.

Roelofs, G.-J. and Lelieveld, J.: Model study of the influence of cross-tropopause $\mathrm{O}_{3}$ transport on tropospheric $\mathrm{O}_{3}$ levels, Tellus B, 49, 38-55, doi:10.1034/j.1600-0889.49.issue1.3.x, 1997.

Rosenlof, K. H.: Seasonal cycle of the residual mean meridional circulation in the stratosphere, J. Geophys. Res.-Atmos., 100, 5173-5191, doi:10.1029/94JD03122, 1995.

Rosenlof, K. H. and Holton, J. R.: Estimates of the stratospheric residual circulation using the downward control principle, J. Geophys. Res.-Atmos., 98, 10465-10479, doi:10.1029/93JD00392, 1993.

Sanderson, M. G.: Effect of Climate Change on Isoprene Emissions and Surface Ozone Levels, Geophys. Res. Lett., 30, 1936, doi:10.1029/2003GL017642, 2003.

Schoeberl, M. R.: Extratropical stratosphere-troposphere mass exchange, J. Geophys. Res.-Atmos., 109, D13303, doi:10.1029/2004JD004525, 2004.

SPARC CCMVal: SPARC Report on the Evaluation of ChemistryClimate Models, edited by: Eyring, V., Shepherd, T. G., and Waugh, D. W., SPARC Report No. 5, WCRP-132, WMO/TDNo. 1526, available at: www.sparc-climate.org/publications/ sparc-reports/ (last access: 28 February 2016), 2010.

Squire, O. J., Archibald, A. T., Abraham, N. L., Beerling, D. J., Hewitt, C. N., Lathière, J., Pike, R. C., Telford, P. J., and Pyle, J. A.: Influence of future climate and cropland expansion on isoprene emissions and tropospheric ozone, Atmos. Chem. Phys., 14, 1011-1024, doi:10.5194/acp-14-1011-2014, 2014.
Stenke, A. and Grewe, V.: Simulation of stratospheric water vapor trends: impact on stratospheric ozone chemistry, Atmos. Chem. Phys., 5, 1257-1272, doi:10.5194/acp-5-1257-2005, 2005.

Stevenson, D. S., Dentener, F. J., Schultz, M. G., Ellingsen, K., van Noije, T. P. C., Wild, O., Zeng, G., Amann, M., Atherton, C. S., Bell, N., Bergmann, D. J., Bey, I., Butler, T., Cofala, J., Collins, W. J., Derwent, R. G., Doherty, R. M., Drevet, J., Eskes, H. J., Fiore, A. M., Gauss, M., Hauglustaine, D. A., Horowitz, L. W., Isaksen, I. S. A., Krol, M. C., Lamarque, J. F., Lawrence, M. G., Montanaro, V., Müller, J. F., Pitari, G., Prather, M. J., Pyle, J. A., Rast, S., Rodriquez, J. M., Sanderson, M. G., Savage, N. H., Shindell, D. T., Strahan, S. E., Sudo, K., and Szopa, S.: Multimodel ensemble simulations of present-day and near-future tropospheric ozone, J. Geophys. Res.-Atmos., 111, D08301, doi:10.1029/2005JD006338, 2006.

Sudo, K., Takahashi, M., and Akimoto, H.: Future changes in stratosphere-troposphere exchange and their impacts on future tropospheric ozone simulations, Geophys. Res. Lett., 30, 2256, doi:10.1029/2003GL018526, 2003.

van Vuuren, D. P., Edmonds, J., Kainuma, M., Riahi, K., Thomson, A., Hibbard, K., Hurtt, G. C., Kram, T., Krey, V., Lamarque, J.-F., Masui, T., Meinshausen, M., Nakicenovic, N., Smith, S. J., and Rose, S. K.: The representative concentration pathways: an overview, Clim. Change, 109, 5-31, doi:10.1007/s10584-0110148-z, 2011.

Wang, Y. and Jacob, D. J.: Anthropogenic forcing on tropospheric ozone and $\mathrm{OH}$ since preindustrial times, J. Geophys. Res., 103, 31123-31135, doi:10.1029/1998JD100004, 1998.

Wild, O.: Modelling the global tropospheric ozone budget: exploring the variability in current models, Atmos. Chem. Phys., 7, 2643-2660, doi:10.5194/acp-7-2643-2007, 2007.

Wild, O. and Akimoto, H.: Intercontinental transport of ozone and its precursors in a three-dimensional global CTM, J. Geophys. Res.-Atmos., 106, 27729-27744, doi:10.1029/2000JD000123, 2001.

WMO: Meteorology - a three-dimensional science: second session of the Commission for Aerology, WMO Bull., 4, 134-138, 1957.

WMO: Scientific Assessment of Ozone Depletion: 2010, Global Ozone Research and Monitoring Project-Report No. 52, World Meteorological Organization, Geneva, Switzerland, 2011.

Yang, H. and Tung, K. K.: Cross-isentropic stratospheretroposphere exchange of mass and water vapor, J. Geophys. Res.Atmos., 101, 9413-9423, doi:10.1029/96JD00057, 1996.

Yang, X., Abraham, N. L., Archibald, A. T., Braesicke, P., Keeble, J., Telford, P. J., Warwick, N. J., and Pyle, J. A.: How sensitive is the recovery of stratospheric ozone to changes in concentrations of very short-lived bromocarbons?, Atmos. Chem. Phys., 14, 10431-10438, doi:10.5194/acp-14-10431-2014, 2014.

Young, P. J., Archibald, A. T., Bowman, K. W., Lamarque, J.-F., Naik, V., Stevenson, D. S., Tilmes, S., Voulgarakis, A., Wild, O., Bergmann, D., Cameron-Smith, P., Cionni, I., Collins, W. J., Dalsøren, S. B., Doherty, R. M., Eyring, V., Faluvegi, G., Horowitz, L. W., Josse, B., Lee, Y. H., MacKenzie, I. A., Nagashima, T., Plummer, D. A., Righi, M., Rumbold, S. T., Skeie, R. B., Shindell, D. T., Strode, S. A., Sudo, K., Szopa, S., and Zeng, G.: Preindustrial to end 21st century projections of tropospheric ozone from the Atmospheric Chemistry and Climate Model Intercomparison Project (ACCMIP), Atmos. Chem. Phys., 13, 20632090, doi:10.5194/acp-13-2063-2013, 2013. 
Yue, X., Mickley, L. J., Logan, J. A., and Kaplan, J. O.: Ensemble projections of wildfire activity and carbonaceous aerosol concentrations over the western United States in the mid-21st century, Atmos. Environ., 77, 767-780, doi:10.1016/j.atmosenv.2013.06.003, 2013.

Zeng, G. and Pyle, J. A.: Changes in tropospheric ozone between 2000 and 2100 modeled in a chemistry-climate model, Geophys. Res. Lett., 30, 1-4, doi:10.1029/2002GL016708, 2003.

Zeng, G., Pyle, J. A., and Young, P. J.: Impact of climate change on tropospheric ozone and its global budgets, Atmos. Chem. Phys., 8, 369-387, doi:10.5194/acp-8-369-2008, 2008.

Zeng, G., Morgenstern, O., Braesicke, P., and Pyle, J. A.: Impact of stratospheric ozone recovery on tropospheric ozone and its budget, Geophys. Res. Lett., 37, L09805, doi:10.1029/2010GL042812, 2010.
Zhang, H., Wu, S., Huang, Y., and Wang, Y.: Effects of stratospheric ozone recovery on photochemistry and ozone air quality in the troposphere, Atmos. Chem. Phys., 14, 4079-4086, doi:10.5194/acp-14-4079-2014, 2014.

Ziemke, J. R., Chandra, S., Labow, G. J., Bhartia, P. K., Froidevaux, L., and Witte, J. C.: A global climatology of tropospheric and stratospheric ozone derived from Aura OMI and MLS measurements, Atmos. Chem. Phys., 11, 9237-9251, doi:10.5194/acp11-9237-2011, 2011. 